\title{
EL PRINCIPIO DE PROTECCIÓN DEL CÓNYUGE MÁS DÉBIL EN EL MODERNO DERECHO DE FAMILIA
}

\author{
THE PRINCIPLE OF PROTECTION OF THE WEAKER SPOUSE IN \\ MODERN FAMILY LAW
}

\section{Cristián Lepin Molina*}

\begin{abstract}
RESUMEN: Las diversas modificaciones que ha sufrido el Derecho de Familia, han incorporado nuevos principios que rigen la materia. En este sentido el principio de protección al cónyuge más débil se presenta como uno de sus principios rectores. Fue incorporado por la Nueva Ley de Matrimonio Civil, por lo que analizaremos su aplicación en las relaciones mutuas entre los cónyuges y especialmente los distintos mecanismos de protección creados por el moderno Derecho de Familia, como son el derecho a compensación económica, la denominada cláusula de dureza y la aprobación judicial del convenio regulador.
\end{abstract}

Palabras clave: Principios, Derecho de Familia, cónyuge débil, divorcio.

ABSTRACT: The various changes of family law have incorporated new principles governing the matter. In this sense the principle of protection of the weaker spouse is presented as one of its guiding principles. It was introduced by the New Civil Marriage Act and this article analyses its application in relations between spouses and particularly, the various mechanisms of protection created by the modern family law, such as the right to financial compensation, the clause of hardness and the court approval of the regulatory agreement.

Key words: Principles Family Law, weak spouse, divorce.

\section{INTRODUCCIÓN}

La Ley $N^{\circ}$ 19.947, Nueva Ley de Matrimonio Civil ${ }^{1}$, que entró en vigencia el 18 de noviembre de 2004, incorporó por primera vez en la legislación chilena el divorcio vincular. Con ello surge desde la presentación del proyecto de ley en el año 1995 y durante toda su tramitación, la preocupación por proteger al cónyuge que al momento de la ruptura queda en una precaria situación económica ${ }^{2}$.

\footnotetext{
Licenciado en Ciencias Jurídicas y Sociales, Abogado, Doctorando en Derecho Civil Universidad de Buenos Aires, Magíster en Derecho por la Universidad de Chile, Profesor de Derecho Civil de la Facultad de Derecho de la Universidad de Chile, de pre y postgrado, Subdirector de la Escuela de Postgrado, de la misma Universidad. Dirección: Avenida Santa María 0200, segundo piso, Providencia. Correo electrónico: clepin@derecho. uchile.cl. Teléfonos 2978 5304- 2978 5307. El autor agradece a los investigadores de la Escuela de Postgrado de la Facultad de Derecho de la Universidad de Chile, Karen Muñoz y Sergio Cortés por su valiosa colaboración en la preparación de este artículo.

1 En adelante NLMC.

2 Así, Instituto Libertad y Desarrollo (2005): Véase Boletín del Senado 1759-18 de la Comisión de Constitución, Legislación, Justicia y Reglamento del Senado, "Aspectos económicos del divorcio" pp. 1170 y ss. Roca Trías (1999) (De la casa a la persona) (Madrid, Cuaderno Civitas) pp. 159-162. Lepin Molina (2012a) pp. $4-5$.
} 
En el proyecto presentado en 1995 por un grupo de diputados de distintas bancadas parlamentarias, representantes de una gran parte del espectro político (con excepción del Partido Unión Demócrata Independiente), la protección del cónyuge débil se expresa a través de la idea de establecer relaciones equitativas entre los cónyuges hacia el futuro y procurar aminorar el daño que pudo causar la ruptura, en los casos de divorcio en que se exigía un convenio regulador o establecer una pensión alimentaria por un tiempo determinado ${ }^{3}$.

Posteriormente, en el segundo trámite constitucional se fortalece la idea de proteger al cónyuge más débil, mediante la incorporación del derecho de compensación económica (artículos 61 a 66 NLMC), la denominada cláusula de dureza que permite al juez rechazar el divorcio en caso de incumplimiento por parte del cónyuge demandante de la obligación alimenticia respecto del otro cónyuge o los hijos (artículo 55 NLMC), y por último, a través del control realizado por el juez al aprobar un convenio regulador, calificándolo de completo y suficiente (artículo 55 NLMC).

A su vez, el legislador chileno incorpora en el artículo $3^{\circ}$ NLMC el deber del juez de familia de resolver los conflictos familiares cuidando proteger siempre el interés superior de los hijos y del cónyuge más débil ${ }^{4}$.

En este trabajo se pretende profundizar sobre el contenido y alcance del principio de protección al cónyuge más débil, de escasa elaboración doctrinaria, y analizar los principales mecanismos de protección establecidos por el legislador en la Ley $\mathrm{N}^{\circ}$ 19.947, para su protección.

\section{PRINCIPIO DE PROTECCIÓN DEL CÓNYUGE MÁS DÉBIL}

Cuando hablamos de principios nos estamos refiriendo, siguiendo a Dworkin, a "un estándar que ha de ser observado, no porque favorezca o asegure una situación económica, política o social que se considera deseable, sino porque es una exigencia de justicia, la equidad o alguna dimensión de la moralidad"5. En el marco de un sistema jurídico basado en el reconocimiento de derechos, puede decirse que los principios son derechos que permiten ejercer otros derechos y resolver conflictos entre derechos igualmente reconocidos ${ }^{6}$.

\footnotetext{
3 En el texto propuesto podemos encontrar dos disposiciones que hacen referencia al tema en comento: el artículo 63, que pretendía establecer el convenio regulador de las relaciones familiares, como una regla común a la separación, nulidad y divorcio, que en su parte final señalaba "es suficiente cuando, al referirse a cada una de las materias que se acaban de señalar, resguarda suficientemente el interés de los hijos, procura aminorar el daño que pudo causar la ruptura y establece relaciones equitativas hacia el futuro entre quienes ahora se divorcian... ", y el artículo 65, que en su inciso final establecía que "al respecto, y por resolución fundada, el juez podrá alterar las reglas de la distribución de gananciales o del crédito de participación, si los hubiere; disponer pensiones alimenticias por tiempo limitado a favor de los cónyuges; o prever otra prestación que asegure a favor de los hijos o el cónyuge relaciones equitativas". La moción parlamentaria que da origen a la Ley $\mathrm{N}^{\circ} 19.947$, presentada el 28 de noviembre de 1995, por la diputada señorita Saa, señoras Allende y Aylwin, y los diputados señores Walker, Barrueto, Cantero, Longton, Munizaga, Elgueta y Viera-Gallo. El destacado es nuestro.

4 Lepin (2012a) p. 5.

5 DorwKin (1989) p. 72.

6 Cillero Bruñol (1998) p. 70.
} 
Para Alexy, los principios "son normas que ordenan que algo sea realizado en la mayor medida posible, dentro de las posibilidades jurídicas y reales existentes" 7 .

Enrique Alcalde distingue entre principio y norma ${ }^{8}$ señalando que la diferencia esencial "radica en la circunstancia de que mientras la segunda supone un marco definido que deslinda su aplicación, aquél, en cambio, al carecer de una descripción precisa del "hecho típico", destinado a regular podría decirse que en sí misma lleva envuelta su indeterminación”. Luego agrega, "por ello, este último constituye una guía, pauta, criterio o, incluso, la causa y justificación de una norma o precepto en particular, pero en ningún caso una "instrucción” exhaustivamente acabada" 9 . Desde nuestro punto de vista, un principio es un mandato dirigido al juez para darle contenido a la ley en el caso concreto, es decir, para que en base a una determinada orientación resuelva la controversia, por decirlo de una manera, legislando en cada caso en particular.

Lo que implica un reconocimiento, por parte del legislador de sus limitaciones, en el sentido que no puede prever todas las situaciones, y que debe depositar la confianza en el juez para que adopte la decisión más conveniente.

Por otra parte, para que este mandato no se transforme en arbitrio, debe el juez reproducir su razonamiento, señalando, por ejemplo, en sus sentencias quién es el cónyuge débil y cuál es la protección que se entrega en el caso en particular ${ }^{10}$. Evitando de esta forma las frases sacramentales que mencionan el principio en la resolución sin fundamentar la decisión.

En consecuencia, el juez debe atenerse a los principios establecidos en la ley cuando interprete y aplique las materias reguladas en ella.

El principio de protección del cónyuge más débil, como se ha señalado, fue incorporado expresamente por la NLMC en el artículo $3^{\circ}$ inciso $1^{\circ}$, que señala "las materias de familia reguladas por esta ley deberán ser resueltas cuidando proteger siempre el interés superior de los hijos y del cónyuge más débil”.

En cuanto a su alcance, recordemos que la NLMC regula lo concerniente a la celebración del matrimonio y la ruptura o quiebre del mismo. Todo lo relativo a las relaciones de los cónyuges durante el matrimonio se regula, en nuestra legislación, en el Código Civil ${ }^{11}$.

\footnotetext{
7 Alexy (2008) p. 67.

8 Sobre la distinción entre principio y reglas cfr. ALEXY (2008) pp. 63 y ss.

9 Alcalde (2003) p. 55.

10 Las exigencias de fundamentación de las resoluciones judiciales se encuentran en la Ley $\mathrm{N}^{\circ} 19.968$ que crea los Tribunales de Familia, a propósito de la valoración de la prueba en conformidad a las reglas de la sana crítica artículos 32 y 66 Nos 4 y 5 que señalan el contenido de la sentencia.

11 Artículo $1^{\circ}$ Ley $N^{\circ}$ 19.947: "La familia es el núcleo fundamental de la sociedad. El matrimonio es la base principal de la familia.

La presente ley regula los requisitos para contraer matrimonio, la forma de su celebración, la separación de los cónyuges, la declaración de nulidad matrimonial, la disolución del vínculo y los medios para remediar o paliar las rupturas entre los cónyuges y sus efectos.

Los efectos del matrimonio y las relaciones entre los cónyuges y entre estos y sus hijos, se regirán por las disposiciones respectivas del Código Civil".

Así, el Código Civil regula lo concerniente al matrimonio en el Título IV "Del Matrimonio" artículos 102 a 123; en el Título V "De las Segundas Nupcias" artículos 124 a 130; en el Título VI "Obligaciones y Derechos entre los cónyuges" artículos 131 a 178; en el Título XXII "De las convenciones matrimoniales y de la sociedad conyugal" artículos 1715 a 1792; y en el Título XXII-A "Régimen de la participación en los gananciales" artículos 1792-1 a 1792-27.
} 
El tenor literal del artículo en comento, se puede concluir que es un mandato dirigido al juez llamado a resolver el conflicto, principalmente en situaciones de quiebre matrimonial. Así el inciso $1^{\circ}$ del artículo $3^{\circ}$ de la NLMC señala "las materias de familia reguladas por esta ley deberán ser resueltas cuidando proteger siempre el interés superior de los hijos y del cónyuge más débil" 12 . En consecuencia, de acuerdo a lo dispuesto en el artículo $3^{\circ}$ NLMC, su aplicación se restringiría a la ruptura, descartando su intervención durante la época que dure el matrimonio.

En las actas de la NLMC existe registro que la preocupación de los legisladores al regular el divorcio vincular era la situación en que quedaban la mujer y los hijos al momento del término del matrimonio, especial interés expresaron por la desigualdad en las condiciones económicas y el poder de negociación ${ }^{13}$ de estos al momento de la ruptura. Así la diputada señorita Saa señaló durante el debate que "en el caso de la nulidad, el matrimonio termina, pero las mujeres y los hijos no tienen fuerza para negociar las condiciones en que quedan. En la práctica la nulidad somete al cónyuge más débil al poder económico del otro. Esto significa que mediante el dinero, el cónyuge más fuerte podrá lograr una nulidad favorable amenazando, por ejemplo, con dejar de pagar la alimentación, la vivienda, la salud y los colegios. El resultado es que el cónyuge más débil se ve obligado a aceptar las condiciones de quien tiene el dinero. Agrega que la realidad indica que la mayoría de los cónyuges más débiles son mujeres, porque el 65 por ciento de ellas no tiene trabajo remunerado y muchas han dedicado su vida a atender el hogar, a los hijos y al marido. Por lo tanto, no tienen asegurada por sí mismas la atención en caso de enfermedad, de invalidez o vejez, o su propia mantención, mientras que los maridos, en su mayoría, perciben una remuneración por su trabajo y financian su previsión con el dinero de la sociedad conyugal"14.

Así también se expresó que "la Comisión acordó tratar separadamente el tema planteado en el artículo $38^{15}$ de la indicación de S. E. el Presidente de la República y en

\footnotetext{
12 El destacado es nuestro.

13 El destacado es nuestro.

14 Boletín del Senado No 1759-18 p. 118. Similares argumentos en las pp. 285, 419 y 433. Lepin (2012a) pp. 6-7.

15 Indicación Proyecto de Ley, artículo 38: "Deberá evitarse que, como consecuencia del divorcio, alguno de los cónyuges quedare imposibilitado de su mantención, considerando las resultas de la liquidación del régimen de bienes que existiere, o el estado de separación de bienes, la existencia de bienes familiares y la eventual provisión de alimentos que hubiere existido entre ellos.

Si el divorcio generare una situación de esa naturaleza, el tribunal podrá adoptar una o más de las siguientes medidas a favor del cónyuge afectado:

a) Proceder a la declaración de bienes familiares.

b) Constituir derechos de usufructo, uso o goce respecto de bienes que hubieren conformado parte del patrimonio familiar de los cónyuges.

c) Determinar el pago de un monto o de una pensión compensatoria por un periodo de tiempo que no exceda de los cinco años, contados desde la fecha en que quede ejecutoriada la sentencia que decreta el divorcio.

Las medidas se adoptarán a petición de parte, pudiendo solicitarse en forma conjunta a la demanda de divorcio o por vía reconvencional en el mismo procedimiento. En ambos casos, deberá resolverse en la sentencia definitiva.

Para acceder a la solicitud y precisar la medida, el tribunal deberá considerar especialmente lo siguiente:

$1^{\circ}$ La duración del matrimonio y de la vida en común de los cónyuges;

$2^{\circ}$ La edad, estado de salud y capacidad económica de ambos cónyuges;

$3^{\circ}$ Las facultades de sustento individual de los cónynges, considerando especialmente las posibilidades de acceso al mercado laboral;
} 
el artículo 48 46 , inciso segundo, de la indicación de los Honorables Senadores señores Chadwick y Romero y del ex Senador señor Díez, acerca de la protección legal que recibiría el cónyuge más débil, en caso de término del matrimonio"17.

En consecuencia, las relaciones personales y patrimoniales entre los cónyuges se rigen por el principio de igualdad ${ }^{18}$, y por excepción, el juez, al momento de la ruptura, deberá aplicar la ley de un modo que beneficie al más débil.

La pregunta es ¿qué entiende la ley por cónyuge más débil? Como la ley no lo señala, debemos recurrir a la doctrina.

Para Pablo Rodríguez se entiende por cónyuge más débil "al que se encuentre en una posición económica, psíquica, emocional o fisiológica desmedrada” ${ }^{19}$.

En un sentido similar, Rodrigo Barcia señala que "pareciera ser que la referencia al "cónyuge débil" no debe entenderse con relación al otro cónyuge por cuanto ello siempre supondría que uno de los cónyuges está en una situación de debilidad. Así, la debilidad del cónyuge debe ser evidente y configurarse por una causa objetiva, como podría ser una enfermedad" 20 .

De aceptar una interpretación tan amplia, como la propuesta, implicaría hacer responsable a un cónyuge de los infortunios que pueda sufrir el otro, en una especie de prolongación del matrimonio más allá de la sentencia de divorcio o nulidad. Como por ejemplo, si durante el juicio de divorcio después de 20 años de separación de hecho, uno de los cónyuges se enferma gravemente.

$4^{\circ}$ La eventual colaboración común que hayan realizado los cónyuges a la actividad que haya servido de sustento al núcleo familiar;

$5^{\circ}$ El aporte y dedicación brindado por los cónyuges a las labores no remuneradas que demanda el cuidado de los hijos y del hogar común;

$6^{\circ}$ La eventual pérdida de beneficios previsionales que deriven del divorcio;

$7^{\circ}$ La existencia previa al divorcio de una pensión de alimentos entre los cónyuges.

Las medidas impuestas en virtud de lo dispuesto en el presente articulo no procederán respecto del cónyuge que haya dado lugar al divorcio por falta que le sea imputable.

En todo caso podrá solicitarse su modificación o cese, si hubieren variado las circunstancias que motivaron el establecimiento.

En los casos previstos en las letras a) y b) del presente artículo, el cónyuge divorciado que no fuere beneficiario de la medida, podrá solicitar al tribunal el cese de la misma una vez transcurridos 5 años desde su imposición, para el solo efecto de proveer su enajenación. En este caso, la resolución que conceda la solicitud deberá determinar el porcentaje de la enajenación que corresponda al cónyuge beneficiario, a titulo compensatorio". El destacado es nuestro.

16 Indicación Proyecto de Ley, artículo 48: "Por la declaración de nulidad se tendrá el matrimonio como no celebrado para todos los efectos legales.

No obstante, el presunto cónyuge que hubiere contraido de buena fe y que haya tenido a su cargo el cuidado del hogar o de los hijos comunes, tendrá derecho a solicitar que el otro cónyuge le proporcione alimentos durante un plazo que no excederá de cinco años contados desde que quede ejecutoriada la sentencia que declara la nulidad". El destacado es nuestro.

17 Boletín del Senado Nº 1759-18 p. 587.

18 Sobre la igualdad entre cónyuges cfr. Domínguez Hidalgo (2005a) pp. 205-218; Corral TAlciani (2009) pp. 37-51; y, Barcia Lehmann (2011) pp. 25 y 26.

19 Rodríguez Grez (2005)

20 Barcia (2011) p. 37. 
En consecuencia, se intenta prolongar el vínculo más allá del divorcio, por lo menos en términos económicos, en una suerte de solidaridad postconyugal. El problema surge por no comprender que el divorcio pone fin al matrimonio y todas las obligaciones tanto personales como patrimoniales que de él derivan (artículo 60 NLMC).

La solidaridad postconyugal ha sido fundamento en España para la pensión compensatoria $^{21}$. En este sentido, Lalana señala que "algunos autores consideran que tiene un fundamento asistencial basado en un principio de solidaridad postconyugal, con lo que se sitúa la razón de ser de la pensión en el matrimonio". Luego, agrega "ciertamente aun cuando no puede defenderse un fundamento asistencial puro, que corresponde a una pensión de alimentos, pero no a una pensión por desequilibrio que puede concederse aunque el cónyuge acreedor tenga una sólida posición económica, la solidaridad postconyugal sí explica en parte que, a pesar de aquel vínculo matrimonial haya desaparecido en caso de divorcio, siga vigente una relación entre los antiguos cónyuges, aunque únicamente sea a efectos económicos”22.

Al igual como señalaba el jurista francés Jean Carbonnier, quien "asienta el deber de alimentos posterior a la ruptura de la convivencia, en una suerte de reminiscencia de la indisolubilidad del matrimonio: una indisolubilidad patrimonial del vínculo, que deja en libertad personal, pero no financiera, al cónyuge culpable"23.

En similar sentido, González señala que "lo que no hay que descuidar en lo absoluto es la conciliación entre el principio de autosuficiencia recién dicho y la solidaridad postdivorcio que los ex cónyuges se deben. Por ello, si la mujer no tiene bienes suficientes o no es posible su reinserción laboral por su edad, el número de hijos, edad de estos, porque no tiene calificación (sic) alguna o por cualquier otra circunstancia, entonces la compensación, por la solidaridad que generó el matrimonio, debe ser tal y cubrir todo aquello que le permita llevar una vida digna y en la medida de lo posible acorde con las condiciones que se tenían antes de la ruptura matrimonial"24.

Por el contrario, Zarraluqui señala que "esta solidaridad postconyugal se cita como uno de los fundamentos del mantenimiento de una obligación pecuniaria, que tiene su origen en un contrato -o institución- ya inexistente por el divorcio o con sus mutuas prestaciones, terminadas o suspendidas indefinidamente por la separación” 25 .

Encarna Roca señala que "si se trata de un resarcimiento por un desequilibrio, mal puede basarse en una solidaridad postdivorcio, puesto comportaría la continuación del matrimonio más allá de su disolución"26.

La solidaridad postconyugal fue un argumento utilizado en el derecho comparado para fundamentar la pensión de alimentos derivada del divorcio por culpa, como una

\footnotetext{
21 Regulada en los artículos 97 a 101 del Código Civil español.

22 Lalana del Castillo (1993) p. 24.

23 Carbonnier, Jean citado por Fosar (1982) p. 389.

24 GonZÁlez (2012) p. 89.

25 Zarraluqui (2003) p. 74. Es menester recordar que en España, de acuerdo a lo prescrito en el artículo 97, la pensión compensatoria procede en los casos de separación y de divorcio: "el cónyuge al que la separación o el divorcio produzca un desequilibrio económico en relación con la posición del otro, que implique un empeoramiento en su situación anterior, tendrá derecho a una compensación...".

26 Roca Trías (1999) p. 190.
} 
sanción adicional al cónyuge culpable de la ruptura matrimonial ${ }^{27}$. No compartimos lo señalado por esta tesis amplia, ya que no cabe duda de que se legisló pensando en proteger a aquel cónyuge que se encontrara, con ocasión del quiebre matrimonial, en un posición de desmedro económico para comenzar su vida de forma separada e independiente ${ }^{28}$. Existe especial preocupación por la mujer que se dedica a las labores del hogar y al cuidado de los hijos, postergando su situación laboral o profesional, ambas situaciones se plasman en los requisitos de procedencia del artículo 61 NLMC.

En la práctica para determinar quién es el cónyuge más débil, es necesario remitirse a los datos entregados por el Instituto Nacional de Estadísticas (INE) en el año 2002. Según estos, el aporte que hombres y mujeres hacen a cada tipo de trabajo es muy diferente. Las mujeres aportan con el 35\% de la fuerza laboral mercantil, lo que significa que un 65\% de ellas están dedicadas al trabajo doméstico no remunerado. Del total de personas que declararon dedicarse a las labores del hogar, el 95\% son mujeres ${ }^{29}$. Según un informe de la Organización Internacional del Trabajo (OIT) a 45\% llegó la participación de las mujeres en la fuerza de trabajo en Chile en el año $2010^{30}$. Aumentando la participación de la mujer en un $10 \%$, pero aún por debajo de la participación en el mercado laboral de los hombres.

En conclusión, la ley entiende que uno de los cónyuges (más débil) queda en una situación de desmedro económico frente al otro cónyuge (más fuerte) al momento del término del matrimonio, ya sea por divorcio o nulidad, que se traduce en sus escasas posibilidades de negociación.

Desmedro que se va a manifestar al término del matrimonio con el retiro del estatuto del matrimonio, en virtud de lo dispuesto en los artículos 50 y 60 NLMC. Así lo expresa Encarna Roca en España, quien señala: "la pensión por desequilibrio constituye una indemnización por la pérdida de los costes de oportunidad alcanzados por un cónyuge durante el matrimonio, que se extinguen como consecuencia del divorcio: mientras era eficaz, el matrimonio enmascaraba esta pérdida a través del deber de socorro; desaparecido el matrimonio, la pérdida se manifiesta con toda su crudeza y por ello debe existir la compensación" 31 .

Si bien es cierto, el término de un matrimonio puede generar otro tipo de consecuencias o daños, como los psicológicos por ejemplo, que no quedan amparados por este principio, y cuya reparación se puede lograr a través de las reglas generales de la responsabilidad civil.

La ley, además de consagrar el principio en comento, establece una serie de mecanismos de protección al cónyuge más débil, como en la compensación económica, en la

\footnotetext{
27 Lepin (2010) pp. 22-23.

28 En este sentido, Guerrero (2008) p. 102. En el mismo sentido Hübner (2005).

29 Gómez de la Torre (2005) p. 5.

30 Según un informe de la Organización Internacional del Trabajo (OIT), a 45\% llegó la participación de las mujeres en la fuerza de trabajo en Chile en 2010, lo cual posiciona a nuestro país en el décimo primer lugar de América Latina en un ranking que lidera Perú con un $62 \%$. El promedio de participación femenina en la región es de 50\%. En tanto, el desempleo femenino en Chile llegó a 10\% en 2010, lo que lo situó en el noveno lugar en América Latina. Disponible en: <http://www.estrategia.cl/detalle_noticia.php?cod=38814> [fecha de consulta: 4 de junio de 2012].

31 Roca (1999) p. 187.
} 
denominada cláusula de dureza y en el control de los acuerdos que presentan los cónyuges en la separación o divorcio solicitado de común acuerdo. Sin perjuicio de ello, se hace necesario analizar previamente la situación del cónyuge más débil en el derecho comparado y en otras instituciones del derecho de familia.

\section{LA PROTECCIÓN DEL CÓNYUGE MÁS DÉBIL EN EL DERECHO COMPARADO}

En el derecho comparado no existe referencia expresa al principio objeto de este estudio, más bien, se entiende que el principio que rige las relaciones entre los cónyuges es el de igualdad. En base a normas constitucionales y de tratados internacionales que impiden la discriminación entre hombres y mujeres. Así, por ejemplo, lo señala expresamente el artículo 66 del Código Civil español : "los cónyuges son iguales en derechos y deberes" 32.

El Tribunal Supremo español se ha pronunciado en igual sentido en causa Rol 6642004, de fecha 14 de septiembre de 2009, que señala "el art. 14.4 CC, redactado de acuerdo con el Decreto 1836/1974, de 31 de mayo y que no fue reformado hasta la ley 11/1990, decía: "la mujer casada seguirá la condición del marido". Se trataba por tanto, de una norma preconstitucional que contenía una flagrante lesión del derecho a la igualdad de los cónyuges, cuando establecía un trato discriminatorio entre el marido y la mujer, dado que imponía a esta una vecindad civil, independientemente de su voluntad, de forma que los sucesivos cambios que experimentara la del marido la iban a afectar a ella, tanto si deseaba adquirirla como si no. Ya hemos citado antes la STC 39/2002, que declaró la inconstitucionalidad sobrevenida y, por tanto, la derogación del Art. 9.2 CC, por ser contrario al principio de igualdad, señalando dicha sentencia que dicha norma "[...] representa una explícita interdicción de determinadas diferencias históricamente muy arraigadas y que han situado, tanto por la acción de los poderes públicos, como por la práctica social, a sectores de la población en posiciones, no solo desventajosas, sino contrarias a la dignidad de la persona reconocida en el Art. 10.1 CE", entre las cuales, evidentemente, se encuentra el sexo como criterio de diferenciación jurídica, que en este supuesto se une el de la igualdad en el matrimonio" 33 .

En similar sentido, la sentencia de fecha 8 de octubre de 2010, en causa Rol 23052006, que señala: "la jurisprudencia ha interpretado el art. 1320 CC como una norma de protección de la vivienda familiar (SSTS de 3 enero 1990 y 31 diciembre 1994). La doctrina, a su vez, considera que con dicho artículo se pretende conseguir la protección de la vivienda, y por ello se protege a uno de los cónyuges contra las iniciativas unilaterales del otro; alguna parte de la doctrina señala que en el fondo de la norma se encuentra el principio de igualdad, que se proyecta en un doble sentido: en el consenso para la elección de la vivienda y en el control de ambos cónyuges para su conservación. El consentimiento se exige para aquellos casos en que el acto de disposición implica la eliminación directa del bien del patrimonio de su propietario, así como aquellos negocios jurídicos, como la hipoteca, que

32 Código Civil español.

33 Disponible en www.poderjudicial.es [fecha de consulta: 5 de septiembre de 2012]. 
llevan consigo posibilidades de que el bien en cuestión desaparezca de dicho patrimonio, por la ejecución en caso de impago de la deuda garantizada con el derecho real"34.

En Francia se destaca la evolución individualista, reflejada en los principios de libertad e igualdad de los cónyuges, expresada en los regímenes patrimoniales, la autoridad paterna, la filiación y el divorcio ${ }^{35}$.

Algo similar ocurre en Argentina, donde se establece la plena igualdad entre los cónyuges sobre la base constitucional determinada por el artículo 16 de la Constitución Nacional, y los tratados internacionales, como el artículo 1 de la Declaración Universal de Derechos Humanos, artículo 11 de la Declaración de los Derechos y Deberes del Hombre, artículo 24 de la Convención Americana sobre Derechos Humanos, artículos 2.2 y 3 del Pacto Internacional de Derechos Económicos, Sociales y Culturales, artículos 3 y 26 del Pacto Internacional de Derecho Civiles y Políticos, artículo 5 de la Convención Internacional sobre Eliminación de todas las Formas de Discriminación Racial, y por último, la Convención sobre Eliminación de todas las Formas de Discriminación contra la Mujer ${ }^{36}$.

Quizás algún atisbo de protección al cónyuge débil, aunque no de manera expresa, se puede encontrar en España en el régimen de separación de bienes, específicamente en el artículo 1438 del Código Civil, que señala: "los cónyuges contribuirán al sostenimiento de las cargas del matrimonio. A falta de convenio lo harán proporcionalmente a sus respectivos recursos económicos. El trabajo para la casa será computado como contribución a las cargas y dará derecho a obtener una compensación que el Juez señalará, a falta de acuerdo, a la extinción del régimen de separación" 37.

La única institución que correspondería analizar bajo este principio sería la compensación económica, regulada en los artículos 97 y siguientes del Código Civil español, 270 y siguientes del Código Civil francés, la pensión de alimentos postdivorcio artículos 1570 y siguientes del Código Civil alemán y la compensación de pensiones artículos 1587 y siguientes del Código Civil alemán, por último, la pensión de alimentos para los cónyuges divorciados de los artículos 207 y 217 del Código Civil argentino, cuyo análisis excede los límites de este trabajo ${ }^{38}$.

\section{LA PROTECCIÓN DEL CÓNYUGE MÁS DÉBIL EN EL DERECHO DE FAMILIA}

Existe una discrepancia en la doctrina en cuanto a la incorporación del principio de protección al cónyuge débil a nuestro ordenamiento jurídico, así se ha entendido que solo fue incorporado por la NLMC, en cambio otros señalan que siempre ha existido en nuestra legislación.

34 Disponible en www.poderjudicial.es [fecha de consulta: 5 de septiembre de 2012].

35 Cfr. Fenouillet (2008) pp. 11-12; y Malaurie y Fulchiron (2009) p. 41.

36 Méndez (2006) pp. 209 y ss.

37 El destacado es nuestro.

38 Cfr. Lepin (2010) pp. 21 y ss.; y Lepin (2008) pp. 91-117. 
Ya hemos señalado que "uno de los principios incorporados a la legislación de familia por la Nueva Ley de Matrimonio Civil es la protección al cónyuge más débil, consagrado en el artículo $3^{\circ}$ NLMC"39.

Pizarro y Vidal sostienen que "considerando la situación precaria en que puede quedar alguno de los cónyuges al término del matrimonio, en particular la mujer que se ha consagrado a la familia y crianza de los hijos, el legislador se preocupó de reconocer el derecho a obtener una "compensación", bajo ciertas circunstancias y parámetros definidos -aunque en forma parcial- en la LMC. Esta preocupación por el cónyuge débil es recogida en la nueva legislación matrimonial. En diversos preceptos se alude a su protección cuya consagración en términos de principio, se establece en el artículo $3^{\circ}$, inciso $1^{\circ}$ "40.

Para Orrego, "no se trata de un principio creado por la Ley de Matrimonio Civil, pues ya estaba consagrado en el Código Civil, por ejemplo, en las normas relativas a los bienes familiares (artículos 141 a 149); en las disposiciones de la sociedad conyugal destinadas a proteger a la mujer (especialmente en lo que se refiere a las limitaciones a la administración ordinaria de la sociedad conyugal, establecidas en el artículo 1749, en las normas que favorecen a la mujer para el pago de las recompensas que se le adeuden, al liquidarse la sociedad conyugal, según lo dispuesto en el artículo 1773, y en el beneficio de emolumento que opera a favor de la mujer, consagrado en el artículo 1777); y en aquellas que se consagran en el crédito de participación en los gananciales, al término de dicho régimen (artículos 1792-20 al 1792-26). Lo mismo ocurre con las normas de alimentos, tanto del Código Civil (artículos 321 al 337) como de la Ley 14.908 sobre Abandono de Familia y Pago de Pensiones Alimenticias)" ${ }^{41}$.

En un sentido similar, Riveros señala "que si bien el principio del cónyuge más débil, ha tenido mayor relevancia con la promulgación de la Ley de Matrimonio Civil y que este principio encuentra su reconocimiento expreso en el Art. 3 Inc. 1 de la LMC, no es menos cierto que, la existencia de un régimen patrimonial en el matrimonio, implica sin duda alguna la protección del cónyuge más débil”².

El problema es dilucidar si el principio en comento es de aplicación general en materia de familia o como ya lo he señalado solo se aplica a las materias reguladas por la NLMC, y específicamente, a la ruptura o quiebre matrimonial.

Esta situación nos conduce a analizar la posible aplicación de este principio en los regímenes patrimoniales, en los bienes familiares y en la pensión de alimentos.

\subsection{EN LOS REgÍMENES PATRIMONIALES}

En el Código de Bello se consideró solo el régimen de sociedad conyugal, siguiendo en esta materia el modelo español previo a la codificación. Señala el artículo 135 que por el solo hecho del matrimonio se produciría sociedad de bienes entre los cónyuges ${ }^{43}$.

\footnotetext{
39 Lepin (2010) p. 62.

40 Pizarro y Vidal (2009) p. 10.

41 Orrego (2004) pp. 20 y 21.

42 Riveros (2012) pp. 421-422.

43 Cfr. Barros (1991) pp. 122-123; Corral (2007b) p. 17.
} 
Como señala Tapia: "las modificaciones del derecho de familia también afectaron profundamente los regimenes de bienes del matrimonio" 44 . En la actualidad los cónyuges pueden optar libremente por los regímenes de sociedad conyugal, separación de bienes o participación en los gananciales ${ }^{45}$.

La sociedad conyugal es el régimen legal y supletorio, es decir, si los cónyuges nada dicen se entienden casados en sociedad conyugal, de lo contrario pueden pactar la separación de bienes o la participación en los gananciales. Lo que puede ocurrir en forma previa al matrimonio en las capitulaciones matrimoniales o en el acto del matrimonio, luego, pueden substituir el régimen por el pacto del artículo 1723 Código Civil, durante el matrimonio $^{46}$.

Corresponde realizar el análisis de los distintos regímenes de bienes del matrimonio a efectos de verificar si tiene aplicación el principio de protección del cónyuge más débil.

\subsubsection{En la sociedad conyugal}

No cabe duda, que la situación de la mujer es bastante distinta a la de la época de la dictación del Código Civil, que en el mensaje señala lo siguiente: "conservando la potestad marital, se ha querido precaver sus abusos y se ha mejorado la suerte de la mujer bajo muchos respectos. Si se suprimen los privilegios de la dote y cesa de todo punto la antigua clasificación de bienes dotales y parafernales llevando adelante la tendencia de la jurisprudencia española, y si la hipoteca legal de la mujer casada corre la suerte de las otras hipotecas de su clase, pues que según el presente proyecto deja de existir y tocará de una vez el término a que las previsiones de la Legislatura han cambiado desde el año 1845; en recompensa se ha organizado y ampliado en pro de la mujer el beneficio de la separación de bienes; se ha minorado la odiosa desigualdad de los efectos civiles del divorcio entre los dos consortes; se ha regularizado la sociedad de gananciales; se han dado garantías eficaces a la conservación de los bienes raíces de la mujer en manos del marido" 47 .

En este régimen es el marido quien es el administrador de los bienes sociales y los bienes propios de la mujer, así lo señala el artículo 1749 Código Civil: "el marido es jefe de la sociedad conyugal, y como tal administra los bienes sociales y los de su mujer". No obstante, en su administración está sujeto a una serie de límites y obligaciones.

\footnotetext{
44 TAPIA (2005) p. 118.

45 Código Civil regula el Libro I, Título IV "Excepciones relativas a la profesión u oficio de la mujer”, en el Título VI “Obligaciones y Derechos entre los cónyuges”, párrafo IV "Excepciones relativas a la separación de bienes”, artículos 152 a 178; y en el Libro IV, Título XXII "De las convenciones matrimoniales y de la sociedad conyugal" artículos 1715 a 1792; y en el Título XXII-A "Régimen de la participación en los gananciales" artículos $1792-1$ a $1792-27$.

$46 \mathrm{Al}$ año 2011, de un total de 66.132 matrimonio celebrados, se casaron en sociedad conyugal 35.823 (54.17\%) en separación total de bienes 28.752 (43.48\%) y en participación en los gananciales 1.557 (2.35\%). En cuanto a la substitución del régimen, pasaron de sociedad conyugal a separación total de bienes 6.072 matrimonios, de separación total de bienes a participación en los gananciales 12 matrimonios y de sociedad conyugal a participación en los gananciales 12 matrimonios, de un total de 6.096 subinscripciones. Fuente: www. registrocivil.cl [fecha de consulta: 25 de septiembre de 2012].

47 Código Civil chileno, p. 2.
} 
Sin embargo, el panorama como señala Corral ha cambiado ${ }^{48}$, ya que desde el año 1925 a la fecha se han incorporado una serie de derechos a favor de la mujer, como por ejemplo, el patrimonio reservado (artículo 150 Código Civil), pacto de separación total de bienes (artículo 1715 inciso $2^{\circ}$ Código Civil), la posibilidad de sustituir el régimen durante el matrimonio (artículo 1723 Código Civil), las limitaciones a la administración del marido (artículo 1749 Código Civil), la acción de separación judicial de bienes (artículos 152 y siguientes Código Civil), la renuncia a los gananciales (artículo 1781 Código Civil), la mujer hará primero las deducciones en la liquidación de la sociedad conyugal (artículo 1773 Código Civil), el beneficio de emolumentos (artículo 1777 Código Civil), entre otros.

Como señala Rodríguez: "a partir de esta constatación, la ley fue evolucionando, generándose una legislación "protectora” de la mujer, atendiendo el hecho de que ella estaba en una situación de menoscabo respecto del marido" 49 .

Sin duda, de lo dicho se desprende claramente que existe una serie de mecanismos compensatorios o protectores a favor de la mujer en la sociedad conyugal, pero ello no deriva de ser el cónyuge más débil, sino del hecho de no tener la administración de la sociedad conyugal.

Otros autores sostienen que tanto la sociedad conyugal como la compensación económica protegen al cónyuge más débil, así por ejemplo se ha señalado: "por lo mismo, no es posible aceptar aquella posición doctrinaria que estima que ambos efectos jurídicos tienen objetivos distintos, debido que el objetivo de ambas instituciones es común, esto es, proteger al cónyuge más débil" 50 .

Resulta difícil compartir dicha opinión, en primer lugar, ya que el principio de protección al cónyuge más débil no distingue, por tanto se puede aplicar al marido o la mujer, en cambio la "protección" dada en la sociedad conyugal se refiere solo a la mujer, y en segundo lugar, si la referencia es exclusivamente a la distribución de los gananciales, estos operan indistintamente si la mujer desarrolló o no actividad remunerada.

Además, en este último caso nuevamente el beneficio es exclusivo para la mujer, la que al término del régimen puede optar por renunciar a los gananciales (si trabajó durante el matrimonio y obtuvo mayores utilidades que el marido) o aceptar los gananciales (si no trabajó o si lo hizo pero obtuvo menores utilidades que su marido).

Como conclusión preliminar, los beneficios establecidos para la mujer en la sociedad conyugal, son una contrapartida por no tener la administración de la sociedad y no por ser el más débil económicamente.

\subsubsection{Participación en los gananciales}

A diferencia de lo que ocurre en la sociedad conyugal, el régimen de participación en los gananciales surge como una alternativa que pretendía consagrar la plena igualdad entre los cónyuges ${ }^{51}$.

\footnotetext{
48 Corral (2007b) p. 18.

49 Rodríguez (1996) p. 11.

50 Riveros (2012) p. 422.

51 Cfr. Barros (1991); Tomasello (1994); Corral (2007b).
} 
Según Ramos, "la Ley N 19.335 optó por la variante crediticia, esto es, que tanto durante su vigencia como a la expiración del régimen, los patrimonios de ambos cónyuges (o del cónyuge sobreviviente y los herederos del difunto) permanezcan separados. Luego, a su extinción, no se genera un estado de comunidad, sino solo se otorga al cónyuge que obtuvo gananciales por menor valor, un crédito en contra del que obtuvo más" 52 .

De lo expuesto, resulta que este régimen pretende establecer el principio de igualdad ante la ley consagrado en la Constitución Política, permitiendo al término del régimen una compensación de los beneficios, como manifestación del principio de solidaridad familiar Así se desprende de lo señalado por Barros al explicar las ventajas del régimen de participación: "expresa adecuadamente la comunidad de vida e interés que constituye el matrimonio. Ello se muestra especialmente durante el matrimonio, al hacer recíprocos los deberes de ayuda y socorro y al reconocer, a diferencia del régimen de separación, la contribución del cónyuge que se dedica al hogar a la economía de la familia. Al terminar el régimen de bienes, los cónyuges, prescindiendo de cual haya sido su contribución efectiva a los aumentos del patrimonio familiar, participan por iguales partes en los gananciales" 53 .

Nos parece en consecuencia que la generación de un crédito de participación al término del régimen, es una manifestación del principio de solidaridad que rige las relaciones entre los cónyuges y otros parientes, que lleva a distribuir en forma equitativa las utilidades que se puedan generar por los cónyuges.

En ningún caso se exige una cierta condición de desmedro o debilidad para poder participar de las ganancias generadas por el otro cónyuge, es decir, el régimen opera independiente de las condiciones en que se encuentren los cónyuges, puede tratarse de dos personas con un importante desarrollo económico, situación en la que es difícil sostener la figura del cónyuge débil.

Este régimen opera con similares características en Francia artículo 1569 y siguientes del Código Civil; en Alemania, artículos 1363 y siguientes, y en España, artículos 1411 y siguientes del Código Civil. En todos ellos existe una distribución de los beneficios al término del régimen económico del matrimonio, pero se sustentan sobre la base de la igualdad entre los cónyuges y la solidaridad propia de las relaciones de familia, en ningún caso se precisa de una situación de debilidad o de necesidad, como ya hemos señalado.

\subsection{BiENES FAMILIARES}

La Ley $\mathrm{N}^{\circ} 19.335$ incorpora a nuestro ordenamiento jurídico la institución de los bienes familiares, lo que según la doctrina constituye un avance en la protección de la vivienda y patrimonio familiar ${ }^{54}$.

Se considera bien familiar "el inmueble de propiedad de ambos cónyuges o de uno de ellos, que sirva de residencia principal a la familia, y los muebles que guarnecen el hogar, y que han sido objeto de una declaración judicial en tal sentido" 55 .

52 Ramos Pazos (2005a) pp. 296- 297.

53 Barros (1991) p. 125.

54 Cfr. Rodríguez (1996) pp. 281 y ss.; Ramos (2005a) pp. 331 y ss.; Corral (2007b) pp. 47 y ss.

55 Rodríguez (1996) p. 281-282. 
La protección de la residencia principal de la familia a través de la declaración de bien familiar, es más bien relativa, dado que el principal efecto de la declaración de bien familiar es limitar la facultad de disposición (enajenar, gravar o prometer enajenar o gravar los bienes familiares) o impedir la celebración de contratos que concedan derechos personales de uso o goce sobre los bienes familiares (artículo 142 Código Civil). Solo eventualmente se pueden constituir derechos de goce sobre dichos bienes a favor del cónyuge no propietario (artículo 147 Código Civil).

De lo expuesto, se puede deducir algunas conclusiones, primero, es una protección a la familia, dado que el objeto a proteger es la residencia principal de la familia; en segundo lugar, protege a la familia fundada en el matrimonio, la acción solo la tienen los cónyuges, las normas que lo regulan se encuentran en el título VI "Obligaciones y Derechos entre los cónyuges”, artículos 141 a 149 del Código Civil, y por último, los artículo 141 a 148 se refieren exclusivamente a los cónyuges.

Así lo ha entendido Corral, que señala: "la institución no pretende proteger intereses individuales de alguno de los cónyuges, sino el interés familiar" 56 . Luego agrega: "la institución de los bienes familiares se fundamenta en el deber de proveer a las cargas de familia y en la protección de la vivienda familiar" 57.

En un sentido similar, Barcia al señalar que "no se puede entender que esta figura protege al 'cónyuge más débil' en un sentido netamente patrimonial, como si solo se compara la fuerza de los patrimonios de los cónyuges. Ello se debe a que como siempre habrá una diferencia patrimonial, necesariamente procedería la declaración de bien familiar, lo que debe desecharse como por (sic) absurdo. Esta figura más bien protege a la familia que al denominado 'cónyuge más débil'" 58 .

\subsection{La PENSión de ALIMENTOS}

Por último, nos queda analizar si la pensión de alimentos resulta ser una manifestación del principio de protección al cónyuge más débil.

El derecho de alimentos se encuentra regulado, principalmente, en el Código Civil artículos 321 y siguientes y en la Ley $N^{\circ} 14.908$ sobre Abandono de Familia y Pago de Pensiones Alimenticias.

Según Vodanovic, se puede entender por alimentos "el derecho que tienen determinadas personas en estado de necesidad, de exigir alimentos a otras también determinadas, las cuales están obligadas a proporcionárselos por mandato de la ley o acuerdo de las partes o por un tercero, como el testador que instituye un legado de alimentos"59.

Para Ramos, se podría definir el derecho de alimentos diciendo que es el que la ley otorga a una persona para demandar de otra, que cuenta con los medios para proporcionárselos, lo que necesite para subsistir acorde con su posición social, que debe cubrir al menos

\footnotetext{
56 Corral (2007b) p. 55.

57 Corral (2007b) pp. 56- 57.

58 Barcia (2011) p. 232.

59 Vodanovic (2004) p. 4.
} 
sustento, habitación, vestidos, salud, movilización, enseñanza básica y media y el aprendizaje de una profesión ${ }^{60}$.

En la legislación española se señala como fundamento de este derecho, según DíezPicazo y Gullón, "al principio de solidaridad familiar, que obliga a los parientes a atender las necesidades vitales que cualquiera de ellos tenga o no pueda satisfacer por sî” ${ }^{\prime}$.

La obligación legal de prestar alimentos, según establece el Código Civil, es una obligación recíproca (aunque no se sanciona expresamente) ${ }^{62}$ que recae generalmente sobre los parientes (artículo 3121 Código Civil).

Sin duda, la prestación alimentaria es expresión de la solidaridad familiar, expresada durante la convivencia conyugal en el deber de socorro (artículo 131 Código Civil) y en la separación de los cónyuges en el derecho de alimentos (artículos 321 y siguientes Código Civil).

Se trata de proporcionar lo necesario para subsistir modestamente de acuerdo a su posición social (artículo 323 Código Civil) y dicha obligación recae en ciertas personas que señala taxativamente la ley (artículo 321 Código Civil), por lo que si alguien no se encuentra en dicha norma, no tiene título para demandar alimentos.

En consecuencia, es una obligación que recae sobre determinadas personas, especialmente, aquellas unidas por un vínculo de parentesco, y por tanto no es privativa de los cónyuges. Es como se ha señalado expresión de la solidaridad familiar, que en el caso de los cónyuges se mantiene hasta el término del matrimonio (artículo 60 NLMC).

\section{MECANISMOS DE PROTECCIÓN CONSAGRADOS EN LA LEY 19.947, NUEVA LEY DE MATRIMONIO CIVIL}

En este apartado corresponde analizar los mecanismos otorgados por el legislador en la NLMC, para proteger al cónyuge más débil, que, por regla general, será la mujer, considerando su participación en el mercado laboral.

Las fórmulas a través de las cuales se concreta este principio son: el derecho a compensación económica, la denominada cláusula de dureza y las facultades del juez para la aprobación del convenio regulador, en los casos de divorcio de común acuerdo.

\subsection{LA COMPENSACIÓN ECONÓMICA}

Se encuentra regulada en los artículos 61 a 66 de la NLMC, y se puede definir como "el derecho que asiste a uno de los cónyuges -normalmente la mujer- cuando, por haberse dedicado al cuidado de los hijos o a las labores propias del hogar común, no pudo durante el matrimonio desarrollar una actividad remunerada o lucrativa, o lo hizo en menor medi-

\footnotetext{
60 Ramos (2005a) p. 519.

61 Díez-Picazo y Gullón (2006) p. 47.

62 Como se sancionan por ejemplo en el Código Civil español en el artículo 143: "Están obligados recíprocamente a darse alimentos...”, y en el Código Civil argentino artículo 367: “...La obligación alimentaria entre los parientes es recíproca”.
} 
da de lo que podía y quería, para que se le compense el menoscabo económico que, producido el divorcio o nulidad, sufrirá por esta causa"63.

La compensación económica procede, según lo prescrito en el artículo 61 NLMC, en los casos de nulidad y de divorcio, excluyéndose el caso de separación judicial, sin perjuicio que el artículo citado se encuentra ubicado en el Capítulo VII de la Nueva Ley de Matrimonio Civil, bajo el epígrafe "De las reglas comunes a ciertos casos de separación, nulidad y divorcio" ${ }^{64}$.

Según Carmen Domínguez, "la única forma de entender esta figura es como "la forma concreta de tutela del cónyuge más débil que la ley contiene. En efecto, es indudable que esta normativa, al introducir el divorcio vincular unilateral, privó al cónyuge más débil que se opone a él de todo poder de negociación. En efecto, este (más bien esta en la mayoría de los casos) ya no dispone de medios para oponerse al divorcio unilateral, de suerte que no tiene modo de evitar la pérdida de todos los derechos que provenían de su relación conyugal"65.

El fundamento de la compensación en el derecho comparado es diverso, así, en España, es restablecer el desequilibrio económico que genera la ruptura matrimonial; en Francia, compensar la disparidad en las condiciones de vida; en Alemania, subvenir en las necesidades económicas del ex cónyuge o compensar los derechos previsionales, y en Argentina, el mantenimiento de las necesidades del ex cónyuge ${ }^{66}$.

Otros autores sostienen que "no es el desequilibrio el factor central de esta figura en el Derecho comparado. Lo esencial en ella es la causa de su establecimiento, que no es otra que proteger y garantizar los acuerdos entre los cónyuges por los cuales se distribuye el trabajo en el seno de la familia. Estos acuerdos se generan dentro del contexto de un matrimonio, dentro del contexto de una familia, que son instituciones que poseen una naturaleza jurídica especial y compleja" ${ }^{37}$.

63 Ramos (2005b).

64 "La Comisión desechó la incorporación de la compensación en los casos de separación judicial, porque en su caso subsiste el matrimonio y precisamente por ello no puede contraerse uno nuevo. No solamente se mantiene el vínculo, sino que también algunos efectos especialmente de orden económico, como son los alimentos entre los cónyuges y los derechos hereditarios, lo que no ocurre con el divorcio y la nulidad. La compensación económica obedece a una lógica distinta, porque al haber divorcio o nulidad se perderán los derechos de alimentos y los hereditarios, así como otros beneficios previstos para el cónyuge, tales como los relacionados con prestaciones de salud o de carácter previsional, lo que no ocurre con la separación", Boletín del Senado $\mathrm{N}^{\circ} 1759-18$, p. 599.

65 Domínguez (2005b) p. 5. En el mismo sentido, las sentencias de la Corte Suprema: González con Brito (2012), Díaz con Fonsekas (2010), Gómez con Anabalón (2010), Barrientos con Barrientos (2010); sentencia de la Corte de Apelaciones de Talca: Beas con Campos (2012); sentencia de la Corte de Apelaciones de Valdivia: Baumgartner con Heinrich (2012); sentencia de la Corte de Apelaciones de Concepción: Zenteno con Zenteno (2012); Sentencia de la Corte de Apelaciones de Santiago: Ruiz con Vial (2011), Bustos con Fernández (2007); sentencia de la Corte de Apelaciones de Temuco: Henzi con Plaza (2011); sentencia de la Corte de Apelaciones de San Miguel: Cabezas con Silva (2007) y Primer Juzgado de Familia de Santiago: López con Galdames (2009).

66 Cfr. artículos 97 y siguientes del Código Civil español, 270 y siguientes del Código Civil francés, la pensión de alimentos postdivorcio artículos 1570 y siguientes del Código Civil alemán y la compensación de pensiones artículos 1587 y siguientes del Código Civil alemán, por último, la pensión de alimentos para los cónyuges divorciados de los artículos 207 y 217 del Código Civil argentino, y Lepin (2010) pp. 21-45.

67 Barcia y Riveros (2011a) p. 253. 
Es más, dichos acuerdos, en el caso de la legislación española, serían contrarios al artículo 68 del Código Civil que señala: "los cónyuges están obligados a vivir juntos, guardarse fidelidad y socorrerse mutuamente. Deberán, además, compartir las responsabilidades domésticas y el cuidado y atención de ascendientes y descendientes y otras personas dependientes a su cargo"68.

De lo que deriva la dificultad para sostener estos “imaginarios" acuerdos sobre la distribución de las labores domésticas, en el derecho comparado (España, Francia y Argentina), máxime, si en la compensación económica, se puede otorgar prescindiendo absolutamente del trabajo doméstico que puede haber realizado uno de los cónyuges ${ }^{69}$. En nuestro país las partes pueden convenir la procedencia de la compensación económica, su monto y su forma de pago $^{70}$, siempre que cumplan con los siguientes requisitos (artículo 63 NLMC), es decir, que: los cónyuges sean mayores de edad, que el acuerdo conste en escritura pública o acta de avenimiento y la aprobación del tribunal.

Las partes son libres para determinar el monto y la forma de pago, cumplidas las formalidades legales. En este sentido, pueden fijar cualquier monto, mediante una cifra única, dividida en cuotas, o mediante la transferencia de determinados bienes, en propiedad o en usufructo, o incluso establecer el pago de una renta vitalicia ${ }^{71}$.

También se puede establecer el monto y forma de pago de la compensación en el acuerdo completo y suficiente, tratándose de un divorcio solicitado de común acuerdo, según lo prescrito en los artículos 55 y 63 NLMC.

A falta de acuerdo, el juez debe regular el derecho a compensación económica, pues está obligado a proteger al cónyuge más débil, determinando la procedencia, cuantía y

68 Código Civil español.

69 Cfr. Lalana del Castillo (1993); Zarraluqui (2003); Fenouillet (2008); Malaurie y Fulchiron (2009); Lepin (2010); y Fanzolato (1993) pp. 21 y ss.

70 Cfr. Lepin (2012a) p. 12.

71 Cfr. Lepin Molina (2012b). Así, respecto a la renta vitalicia, sentencia del Segundo Juzgado de Familia de Santiago Sasmay con Oliver (2007): "con fecha 13 de noviembre del presente año, se prosiguió con la audiencia preparatoria, manifestando las partes que llegaron a acuerdo en materia de compensación económica en los términos registrados en el audio y que se resumen de la siguiente forma: la demandante confiere mandato irrevocable a su cónyuge, para que este en su nombre y representación ejerza todos sus derechos en la sociedad XX Ltda., como contraprestación a ello su cónyuge se obliga al pago de una renta vitalicia en beneficio de la demandante de compensación, por un monto de $\$ 1.400 .000$.-, reajustables de conformidad a la variación del IPC o el factor que lo reemplace, cada seis meses, la que se devengará a contar de la fecha de inscripción del divorcio, en los términos señalados y registrados en audio, agregando finalmente que en el tiempo intermedio, el demandado reconvencional pagará por concepto de pensión de alimentos, la misma suma y en los mismos términos a la demandante. Dicho acuerdo se tuvo por aprobado en audiencia" (aprobada por la Ilustrísima Corte de Apelaciones de Santiago, Rol 781-2008). En el mismo sentido sentencia de la Corte de Apelaciones de San Miguel Cabezas con Silva (2007), ha señalado que "debe aprobarse el acuerdo suscrito por los cónyuges en escritura pública en el cual convienen el pago de una compensación económica a favor de la demandada de divorcio, transfiriéndole un inmueble y efectuando pagos bajo la forma de pensión vitalicia, ya que todo esto importa un reconocimiento sobre la procedencia de la compensación económica y de la forma de pago de la misma, por lo que al juez solo le corresponde considerar si se cumplen o no los requisitos que la ley exige para que se dé lugar a ella. En efecto, procede aprobar el acuerdo, ya que teniendo un carácter patrimonial la compensación económica, que admite su renuncia, a contrario sensu se puede concluir que su otorgamiento por parte del demandado constituye una opción libre para concederla. Considerándola así, y en armonía con el principio de protección del cónyuge más débil, se supera lo estricto de la norma del artículo 61 NLMC”. 
forma de pago. Al establecer la cuantía, deberá fijar el monto en una unidad reajustable y seguridades para el pago de la misma ${ }^{72}$.

Otra norma de protección se encuentra en el deber de informar sobre el derecho a compensación económica, consagrado en el artículo 64 NLMC. Si el juez no cumple con esta obligación, procede el recurso de casación en la forma de acuerdo a lo prescrito en el artículo $768 \mathrm{~N}^{\circ} 9$ Código de Procedimiento Civil, ya que se trata de un trámite esencial ${ }^{73}$.

Relacionado con lo anterior se encuentra la oportunidad para demandar compensación económica, según señala el artículo 64 NLMC, solo se puede hacer en la demanda, escrito complementario de la demanda, o en la demanda reconvencional. Sin embargo, dado este deber de informar, si el cónyuge más débil no presentó su acción en dicha oportunidad, el juez puede autorizar, basado en la protección del cónyuge más débil, que presente su demanda en la misma audiencia preparatoria, situación que en estricto rigor no procede, ya que precluyó el derecho.

En materia de pago de la compensación económica, la regla general es que deberá hacerse mediante la entrega de una suma de dinero, determinada e invariable ${ }^{74}$, preferentemente en un solo acto ${ }^{75}$.

La firme intención del legislador es querer concentrar la determinación de la cuestión económica en un solo momento. Por lo mismo, razona sobre la idea que el monto de la compensación debe ser fijado en la sentencia y en una suma única y total que no admite revisión futura. Esto resulta ostensible de su regulación, pero también de la historia fidedigna en el Senado, de cuyo debate puede obtenerse que el esfuerzo permanente de quienes más intervinieron en él, fue evitar que las cuestiones económicas dieran lugar a conflictos permanentes entre los ex cónyuges. Incluso se llegó a fundar esta forma de fijación de la compensación en que las personas de menores recursos "también tienen derecho a reconstruir su familia y vivir

\footnotetext{
72 Lepin (2010) p. 139.

73 Así lo ha resuelto la Corte de Apelaciones de Valdivia: Álvarez con Raimilla (2007); sentencia de la Corte de Apelaciones de Talca: Flores con Mora (2006). La Corte Suprema ha decidido también invalidar de oficio la sentencia por incumplimiento del deber de informar, así en Espinoza con Miranda (2012).

74 La Excelentísima Corte Suprema, en sentencia Salgado con Bustos (2009), ha resuelto "que, a falta de acuerdo entre las partes, corresponde al juez de la causa establecer si se dan los requisitos que la institución exige y fijar su monto. De relacionar los artículos 63, 64, 65 y 66 de la Ley 19.947, se infiere que el legislador ordena pagar un monto determinado invariable en el tiempo, cualquiera sean las circunstancias personales y patrimoniales de los interesados -deudor o acreedor- posteriores a la sentencia que la regula".

75 En este sentido existe mayor similitud con la legislación francesa, en que se privilegia su fijación en una prestación única o a tanto alzado, artículo 273 Código Civil francés; a diferencia de la legislación española, en que se puede regular como una pensión temporal o por tiempo indefinido, o como prestación única, artículo 97 Código Civil español. De igual forma se ha resuelto en nuestro país, en sentencia de la Corte de Apelaciones de Concepción, Ramírez con Godoy (2009), que señala: "el legislador no ordena pagar una pensión mensual, sino un monto determinado que es invariable... Luego, la compensación económica, será pagada de una sola vez, y por excepción, según lo dispuesto en el artículo 66 de la Ley de Matrimonio Civil, el legislador autoriza su pago en cuotas". En igual sentido, la profesora Veloso ha señalado: "la ley contempla diversas posibilidades para su entero y pago. Con todo, puede sostenerse que la idea principal es pagarlo de una sola vez; de esta manera se evitan los inconvenientes del pago periódico, circunstancia potencialmente conflictiva a la luz de la experiencia comparada. Nótese que en Chile no se le denomina pensión, como en otros países, terminología que puede conllevar a la idea de periodicidad", en Veloso (2007) p. 185.
} 
en paz" sin que deban estar obligados a tener que destinar el mayor porcentaje de su sueldo a la mantención de la familia antigua y no a sostener su familia nueva ${ }^{76}$.

El dinero podrá ser enterado en una o varias cuotas reajustables. Se faculta al juez para fijar cualquier forma de reajuste. La experiencia en los Tribunales de Familia en materia de pensiones alimenticias considera el alza que experimente el Índice de Precios al Consumidor (IPC), que fija el Instituto Nacional de Estadísticas (INE), o un porcentaje del ingreso mínimo remuneracional, que se reajusta por ley una vez al año, o también expresar el monto en unidades de fomento (UF) o unidades tributarias mensuales (UTM) ${ }^{77}$.

Respecto de las cuotas, el juez fijará seguridades para su pago. Por ende, el juez podrá ordenar la constitución de una caución, ya sea, ordenar la constitución de una hipoteca o de una prenda, sobre bienes determinados por parte del cónyuge deudor, o disponer que el empleador del cónyuge deudor retenga el monto a $\operatorname{pagar}^{78}$, deduciéndolo de la remuneración del obligado ${ }^{79}$. También se ha señalado que podría establecer una cláusula de aceleración del crédito ${ }^{80}$.

Existen otras modalidades de pago como la entrega de acciones u otros bienes. Se trata de la transferencia del dominio de ciertos bienes que pueden ser muebles o inmuebles, acciones u otros valores. También, la constitución de derechos de usufructo, uso o habitación, respecto de bienes que sean de propiedad del cónyuge deudor. La constitución de estos derechos no perjudicará a los acreedores que el cónyuge propietario hubiere tenido a la fecha de la constitución, ni aprovechará a los acreedores que el cónyuge beneficiario tuviere en cualquier tiempo.

Por último, el juez podrá ordenar el traspaso de fondos desde la cuenta de capitalización individual, conforme al Decreto Ley $\mathrm{N}^{\circ} 3.500$, del cónyuge que deba compensar a la cuenta de capitalización del cónyuge compensado, o de no existir esta, a una cuenta de capitalización individual que se abra al efecto. Dicho traspaso no podrá exceder del $50 \%$ de los recursos acumulados en la cuenta de capitalización individual del cónyuge que debe compensar, respecto de los fondos acumulados durante el matrimonio ${ }^{81}$.

Por lo tanto, el juez a falta de acuerdo de las partes deberá fijar la forma de pago, solo en caso de que no se pueda aplicar las formas mencionadas (artículo 65 NLMC), el juez puede fijar las cuotas necesarias, considerando la capacidad económica del deudor y las cuotas respectivas se considerarán alimentos para efectos de su cumplimiento (artículo

\footnotetext{
76 Domínguez (2005b) pp. 5 y 6.

77 LePIN (2010) p. 145.

78 Corte de Apelaciones de Santiago, en sentencia Guzmán con Filippi (2007): “...Y visto, además, lo dispuesto en el artículo 67 de la Ley 19.968, se revoca, en lo apelado, la sentencia de dieciséis de mayo de dos mil seis y en su lugar se decide que se acoge la demanda reconvencional del primer otrosí de fojas 18 , solo en cuanto se condena al demandante y demandado reconvencional a pagar a la actora reconvencional la suma de dinero equivalente a 310 (trescientas diez) unidades de fomento, pagadera en sesenta cuotas mensuales de 5,16 unidades de fomento cada una, debiendo solucionarse por medio de retención que practicará la respectiva institución previsional, a contar del mes siguiente a la fecha en que esta sentencia quede ejecutoriada, sin costas por haber tenido el demandado reconvencional motivos plausibles para litigar". El destacado es nuestro.

79 Lepin (2012b) pp. 92 y 93.

80 Gómez de la Torre (2005) p. 16.

81 Artículo 80 Ley $\mathrm{N}^{\circ} 20.255$ establece reforma previsional. Cfr. Lepin (2010) pp. 127 y ss.
} 
66 NLMC), en este caso el legislador protege al cónyuge más débil asimilando la cuotas de compensación económica a la obligación alimenticias para efectos de hacer procedentes los apremios. Se discute si se aplican todos los apremios de los alimentos, como la reclusión nocturna, pero este tema excede los límites del presente trabajo.

Otro aspecto a destacar, es la posibilidad de la renuncia al derecho a compensación económica, mirado desde el punto de vista de la protección al cónyuge más débil. Así, el problema de la renuncia se puede analizar ex ante, en las capitulaciones matrimoniales, durante el matrimonio, o en el proceso de nulidad o divorcio. Sin duda el tema se relaciona con la determinación de la naturaleza jurídica ${ }^{82}$ y con el carácter patrimonial ${ }^{83}$ o extrapatrimonial ${ }^{84}$ de la prestación compensatoria.

La mayoría de la doctrina nacional se inclina porque la renuncia anticipada no sería válida. En este sentido, se ha sostenido por Corral "que esta renuncia anticipada sería inválida. Se trata de un derecho personalísimo del cónyuge sobre el cual no proceden actos de disposición" 85 . De igual modo, para Vidal "no es posible admitirla, y para ello me apoyo en tres argumentos: a) el interés protegido por la compensación económica -el del cónyuge más débil- es de orden público y, por consiguiente, indisponible anticipadamente; b) si se admite que la regulación de la compensación económica puede ser objeto de una capitulación matrimonial, el límite de la libertad de pacto de los esposos, según el artículo 1717 del Código Civil, está en el detrimento de los derechos y obligaciones que las leyes señalan a cada cónyuge respecto del otro, y entre ellos, no hay duda, está el derecho a la compensación y su obligación correlativa; c) si bien la regla en materia de compensación económica es que ella sea convencionalmente regulada por los cónyuges, es menester la observancia de una solemnidad, en la especie, la aprobación judicial (artículo 63 de la Ley de Matrimonio Civil)"86.

En este sentido, ya hemos señalado que se trata de un derecho establecido a favor del cónyuge más débil, incluso se estima como el principal mecanismo para su protección, por lo que podríamos considerarla como una norma de orden público, indisponible para las partes. Además, si consideramos que el derecho nace solo en el marco del juicio de nulidad o divorcio, por lo que antes y durante el matrimonio es una mera expectativa y no un derecho, lo que se corrobora porque no se puede solicitar durante el matrimonio, ni tampoco es posible solicitar este derecho en sede de separación judicial ${ }^{87}$.

En consecuencia, en el marco del juicio de divorcio sería plenamente válida la renuncia, se trataría de un derecho que solo mira el interés del renunciante (artículo 12 Código Civil) ${ }^{88}$.

En España, la renuncia previa o anticipada, ya sea anterior al juicio o incluso al matrimonio, entiéndase en las capitulaciones matrimoniales, según la profesora Encarna Roca, es perfectamente posible, al no tener naturaleza alimenticia, no se puede aplicar el

\footnotetext{
82 Cfr. Pizarro y Vidal (2011) pp. 18- 39; Lepin (2010) pp. 71-94; y Lepin (2012c) pp. 81-96.

83 Barrientos (2007) pp. 9-44; Novales (2010) pp. 35-72.

84 Barcia y Riveros (2011a) pp. 249-278.

85 Corral (2007a) p. 36. En el mismo sentido, Domínguez (2005b) pp. 14-15.

86 VIDAL (2006) p. 277.

87 LEPIN (2010) p. 158.

88 Gómez de LA Torre (2005) p. 18.
} 
art. 151.1 CC, cuando se reconoce a la pensión la naturaleza de derecho resarcitorio por un daño derivado de la separación o el divorcio, por lo que queda englobado en el derecho de las obligaciones, que permite la renuncia previa a las acciones de indemnización, art. 1102 CC, y en el caso de las capitulaciones matrimoniales, el art. 1328 CC, parece no eliminar esta posibilidad. En contra, Gabriel García Cantero sostiene que "no es un derecho libremente disponible, es de derecho necesario, y en consecuencia no renunciable. Sin embargo, estima que una vez concedida, es admisible su renuncia" 89 .

Céspedes y Vargas han señalado "que no estamos ante un derecho personalísimo, es decir, de aquellos que no pueden renunciarse, transferirse ni transmitirse, porque, de ser así, el legislador lo habría dicho expresamente. Así, por ejemplo, en el derecho de uso y habitación, derecho personalísimo por excelencia, el legislador ha prohibido expresamente su transferencia y transmisión en el artículo 819 CC. Esta, creemos, es la razón de por qué la ley estableció expresamente la prohibición de renunciar al crédito de participación en los gananciales, porque, de lo contrario, habría sido perfectamente renunciable. De otro punto de vista, si se puede renunciar a los gananciales de la sociedad conyugal anticipadamente, que, en teoría, son de mayor entidad que el crédito de participación, no avizoramos razones para negar la renunciabilidad anticipada de la compensación económica" 90 .

En forma similar Pizarro y Vidal "de aceptarse la renuncia, debe regirse por las reglas generales aplicables al contrato, por lo cual puede resultar ineficaz en el evento de que se infrinjan reglas imperativas. Rige, en consecuencia, el principio de la buena fe contractual, lo cual puede servir para remediar un desequilibrio grave en el pacto. Además, no debe incurrirse en algún vicio del consentimiento causal de nulidad del contrato. Por último, y en conformidad al citado artículo 12, no podrá otorgarse validez al pacto en caso de lesión a intereses de terceros" ${ }^{\prime 1}$.

Por otro lado, se ha señalado "que la renunciabilidad a la compensación económica está determinada por los principios y directrices del Derecho de Familia y, en especial, por el principio de protección al cónyuge débil. Por ende, los pactos en que se renuncie a la compensación económica deben ser objeto de un control de contenido ex-post al acuerdo, desde la perspectiva mencionada" 92 . Luego agregan: "por otra parte, la aplicación del principio de protección del cónyuge débil solo procede en la medida que la compensación económica sea exclusivamente asistencial o en la parte que lo es, como si concurren criterios resarcitorios conjuntamente con criterios asistenciales. En dicho análisis el juez debe efectuar un análisis global de los distintos efectos jurídicos del divorcio y de la nulidad. Así, es distinto renunciar a la compensación económica y suscribir un régimen de separación total de bienes, que realizar esta misma renuncia pactando un régimen de participación en los gananciales, en la cual el cónyuge renunciante salga ganancioso. El juez no puede dejar de analizar la situación patrimonial final de los cónyuges"93.

\footnotetext{
89 Roca Trías y García Cantero. Ambos citados por Zarraluqui (2003) pp. 136 y 137.

90 Cespedes y Vargas (2008) pp. 454 y 455.

91 Pizarro y Vidal (2009) p. 127.

92 Barcia y Riveros (2011b) p. 108.

93 Barcia y Riveros (2011b) p. 109.
} 
De lo expuesto solo compartimos la referencia al cónyuge más débil, ya que nos parece que los autores confunden la naturaleza jurídica de la compensación económica con sus fundamentos. En este sentido, la referencia al carácter asistencial ${ }^{94}$ no corresponde a ninguna figura jurídica de derecho privado, salvo que sea un recurso semántico para referirse a los alimentos que terminan conjuntamente con la sentencia de divorcio (o quizás se podría plantear en el derecho público o como una obligación del Estado).

Tampoco se puede sostener el control ex-post propuesto, dado que si un cónyuge renuncia a la compensación económica no se aplican los criterios del artículo 62 NLMC, no se debe rendir prueba sobre ello, por lo que en la práctica el juez no va a contar con antecedentes para determinar si es asistencia o mixta, a fin de poder aprobar o rechazar la renuncia en el modelo propuesto.

De esta forma la compensación económica es una manifestación de un principio de carácter general del derecho, la equidad, que en el caso de la legislación chilena, faculta al juez para corregir la desigualdad entre los cónyuges proveniente del menoscabo económico que la ruptura puede generar en el cónyuge más débil.

Manifestaciones de este principio de protección al cónyuge débil en la compensación económica son el deber de informar (artículo 64 NLMC), formas de pago, reajustes y seguridades para el pago (artículo 65 NLMC) y, por último, la aplicación de los apremios de la Ley $N^{\circ} 14.908$ sobre Abandono de familia y Pago de Pensiones Alimenticias (artículo 66 NLMC).

\subsection{LA DENOMINADA CLÁUSULA DE DUREZA}

Otro de los mecanismos diseñados por el legislador chileno, es la denominada cláusula de dureza, que permite al juez rechazar el divorcio por cese de convivencia solicitado unilateralmente, cuando a solicitud de la parte demandada, verifique que el demandante, durante el período de cese de convivencia, no dio cumplimiento, en forma reiterada, a su obligación de alimentos, respecto del cónyuge demandado y de los hijos comunes, pudiendo hacerlo (artículo 55 inciso $3^{\circ}$ NLMC) ${ }^{95}$.

Así lo ha resuelto la Corte Suprema, en sentencia de 23 de mayo de 2011, que señala "que el inciso tercero del artículo 55 de la ley $\mathrm{N}^{\circ}$ 19.947, previene que no se dará lugar al divorcio si el demandante durante el cese de la convivencia “...no ha dado cumplimiento, reiterado, a su obligación de alimentos respecto del cónyuge demandado y de los hijos comunes", la finalidad de la disposición, es sancionar la infracción a la obligación de socorro y el principio de protección al cónyuge más débil"96.

\footnotetext{
94 Según la RAE, asistencial es lo "perteneciente o relativo a la asistencia, especialmente la médica o la social" y asistencia, en lo pertinente, "acción de prestar socorro, favor o ayuda", o los "medios que se dan a alguien para que se mantenga".

95 Artículo 55 inciso $3^{\circ}$ NLMC: "Habrá lugar también al divorcio cuando se verifique un cese efectivo de la convivencia conyugal durante el transcurso de, a lo menos, tres años, salvo que, a solicitud de la parte demandada, el juez verifique que el demandante, durante el cese de la convivencia, no ha dado cumplimiento, reiterado, a su obligación de alimentos respecto del cónyuge demandado y de los hijos comunes, pudiendo hacerlo".

96 Sentencia Corte Suprema: Malebrán con Corral (2011).
} 
Según Jorge del Picó, se trata de la "inclusión de un criterio restrictivo aplicado al derecho de demandar el divorcio en la modalidad unilateral, por una norma inspirada en la experiencia comparada, conocida como cláusula de dureza. Propiamente tal, no es la institución que, en doctrina, se conoce también como cláusula de rigor, pero comparte con ella la posibilidad reconocida al juez, de poder negar el divorcio cuando observa que existe una alta probabilidad de generar daños mayores que se puedan provocar en aquellos casos en que este sea otorgado, como por ejemplo, la precariedad de los medios para la subsistencia económica de los hijos o del cónyuge, o que teniendo o no relación con el hecho del divorcio, se agrave la enfermedad que padece una persona, de quien el demandante pretende divorciarse. Esta cláusula o norma de rigor, constituye una limitación al régimen de divorcio en las leyes civiles contemporáneas, y se puede apreciar en el Código Civil alemán, en el Código francés y en el Derecho inglés"97.

Más allá de la diferencia semántica, lo concreto es que se trata de otra aplicación del principio de protección al cónyuge débil y de protección a los hijos, constituyéndose en un verdadero apercibimiento para el demandante de divorcio, en el caso de no cumplir con el pago de la pensión de alimentos.

Como señala Jorge del Picó, "la introducción de este precepto, con el propósito señalado, ha sido motivado principalmente por razones de equidad social y con el fin de aminorar los efectos en las personas más vulnerables de la familia afectada por un quiebre o ruptura matrimonial" 98 .

Esta excepción tiene lugar, de acuerdo a lo prescrito en el artículo 55 NLMC, cuando el juez, a solicitud de la parte demandada, verifique que la parte demandante durante el cese de la convivencia no ha dado cumplimiento, reiterado, a su obligación de alimentos respecto del cónyuge demandado y de los hijos comunes, pudiendo hacerlo.

La expresión "verifique", que utiliza el legislador, puede dar lugar a dos interpretaciones. En primer lugar, que se otorgan facultades de oficio al juez para indagar sobre la existencia del incumplimiento; esto es coherente con las normas que rigen esta materia en los Tribunales de Familia, artículo 29 LTF $^{99}$, que ordena traer causas a la vista o incorporar otros documentos que acrediten el incumplimiento. En segundo lugar, que se aplique la regla general, es decir, quien alega el incumplimiento deberá probarlo conforme al artículo 1698 Código Civil; interpretación que parece de toda lógica, considerando que se trata de un hecho negativo.

En relación a este tema surge otra interrogante: ¿hasta qué momento se puede alegar este incumplimiento?, ¿en cualquier etapa del juicio? En principio, estimamos que las alegaciones de las partes y el debate deben quedar concluidos en la audiencia preparatoria, lo que otorga un mínimo de certeza jurídica. Sin perjuicio de ello, sostenemos que se puede alegar en la contestación de la demanda o en forma incidental durante la audiencia. Esto

97 Del Picó (2010) p. 432.

98 Del Picó (2010) p. 432.

99 Artículo 29 inciso final Ley $\mathrm{N}^{\circ}$ 19.968: "El juez, de oficio, podrá asimismo ordenar que se acompañen todos aquellos medios de prueba de que tome conocimiento o que, a su juicio, resulte necesario producir en atención al conflicto familiar de que se trate". 
por aplicación del artículo $9 \mathrm{LTF}^{100}$ que señala que el procedimiento de familia será desformalizado. Esta interpretación permite un justo equilibrio entre la defensa de los intereses de los más débiles y la necesaria certeza jurídica.

El efecto de la "cláusula de dureza" es facultar al juez para denegar o rechazar el divorcio unilateral, siempre que se cumplan los siguientes requisitos copulativos ${ }^{101}$ :

a) Solicitud de parte;

b) Que esté determinada judicialmente la pensión de alimentos;

c) Que exista un incumplimiento reiterado durante el cese de la convivencia de la obligación alimenticia, respecto del cónyuge y de los hijos comunes, y

d) Que este incumplimiento sea injustificado.

A nuestro juicio, para que proceda la cláusula de dureza se requiere de una solicitud de parte ${ }^{102}$, que correspondería a una excepción perentoria ${ }^{103}$ destinada a enervar la acción de divorcio. Aunque también se ha entendido que se trata de un presupuesto de la acción (un requisito de la acción de divorcio). La primera interpretación resulta más armónica con el texto legal, que expresamente señala "a solicitud de la parte demandada", y con la naturaleza de la excepción.

Será menester que se haya decretado judicialmente la pensión de alimentos ${ }^{104}$, la NLMC no distingue si se debe tratar de alimentos definitivos o provisorios, por lo que basta que se regulen en forma provisoria, ya que de acuerdo a lo dispuesto en el artículo 331 del Código Civil ${ }^{105}$, los alimentos se deben desde la primera demanda, en estricto rigor desde la notificación de la misma ${ }^{106}$.

\footnotetext{
100 Artículo $9^{\circ}$ Ley $\mathrm{N}^{\circ}$ 19.968: "Principios del procedimiento. El procedimiento que aplicarán los juzgados de familia será oral, concentrado y desformalizado. En él primarán los principios de la inmediación, actuación de oficio y buisqueda de soluciones colaborativas entre partes".

101 En forma similar, sentencia de la Corte Suprema Acuña con Orozco (2010).

102 En igual sentido, sentencia de la Corte de Apelaciones de Copiapó León con Valdivia (2010).

103 Así, sentencia de la Corte Suprema: Elgueta con Piñeyro (2009), que señala: "al respecto, cabe señalar que la ley reconoce al contrayente demandado la posibilidad de enervar la acción de divorcio pidiendo al Juez que verifique que el actor durante el cese de la convivencia no ha dado cumplimiento, reiteradamente, a su obligación en calidad de alimentante. Se trata pues de una excepción perentoria que debe ser alegada por el cónyuge afectado y el peso de la prueba, por aplicación de la regla general del artículo 1698 del Código Civil corresponde al actor". Se trata de una excepción perentoria dado que se trata de una defensa que el demandado opone a las pretensiones jurídicas del actor, en este caso sin referirse al fondo de la acción deducida (cese de convivencia) pero que produce el efecto de enervar la acción.

104 De acuerdo al artículo 331 del Código Civil chileno, los alimentos se deben desde la primera demanda, lo que implica necesariamente una regulación judicial de los mismos, por lo menos en forma provisoria.

105 Artículo 331 Código Civil: "Los alimentos se deben desde la primera demanda, y se pagarán por mesadas anticipadas.

No se podrá pedir la restitución de aquella parte de las anticipaciones que el alimentario no hubiere devengado por haber fallecido”.

106 Gómez de LA Torre (2007) p. 196.
} 
Por otro lado, el incumplimiento debe ser reiterado ${ }^{107}$. Que sea reiterado significa que el incumplimiento debe ser sucesivo en el tiempo, que sea repetido. Pero el texto legal no exige la aplicación de apremios de la Ley $\mathrm{N}^{\circ} 14.908^{108}$, a diferencia de lo que ocurre en el artículo 19 de la misma ley ${ }^{109}$, que exige que conste en el proceso que se hubiere decretado dos veces alguno de los apremios señalados en los artículos 14 y 16, para hacer procedentes alguna de las sanciones que se establecen en dicha disposición. La ley no exige que se hayan decretado apremios, ni mucho menos su reiteración ${ }^{110}$.

Aunque la ley no lo señala, será necesario que se solicite la liquidación de la deuda de pensiones alimenticias devengadas, ya que, de otro modo, no es posible determinar el incumplimiento. De esta forma la inactividad de la demandada de divorcio durante más de diez años, donde jamás exigió el pago sino hasta que fue notificada de la demanda de divorcio, ha permitido concluir que no necesitó de dicha pensión alimenticia para su subsistencia y en ese sentido puede concluirse que no se dan los presupuestos que tuvo presente el legislador ${ }^{111}$ para el establecimiento de esta cláusula.

Por último, el incumplimiento debe ser injustificado, como señala el artículo 55 al expresar "pudiendo hacerlo", similar al artículo 225 Código Civil, y que exime de esta carga a quien no está en condiciones de cumplir por causas ajenas a su voluntad, como por ejemplo en caso de quiebra del alimentante ${ }^{112}$ o cesantía ${ }^{113}$, tratándose de situaciones gra-

107 En sentencia de la Corte de Apelaciones de Concepción, Aravena con Ramírez (2009), desestimó la alegación de incumplimiento, ya que, este debe ser reiterado, "cabe señalar que (en el caso de autos) existe un solo incumplimiento (de la obligación alimenticia), pues se trató de un solo requerimiento, producto de una liquidación, aunque incluya dos mensualidades, de manera que no se encuentra en la situación de incumplimiento reiterado, situación que no impide acceder a la demanda de divorcio". En similar sentido, la Corte Suprema, en sentencia Lagos con Monsalve (2008), señala que "las circunstancias del caso no permiten calificar el pretendido incumplimiento atribuido al actor como reiterado, atendido el período de tiempo en que este cumplió con el pago de las pensiones alimenticias fijadas a favor de los alimentarios y el hecho de no haber instado la afectada por el cumplimiento forzado de aquellas".

108 Artículos 14 y 16 de la Ley N 14.908 sobre Abandono de Familia y Pago de Pensiones Alimenticias. Disponible en <www.leychile.cl>.

109 Artículo 19 Ley $\mathrm{N}^{\circ}$ 14.908: "Si constare en el proceso que en contra del alimentante se hubiere decretado dos veces alguno de los apremios señalados en los articulos 14 y 16, procederá en su caso, ante el tribunal que corresponda y siempre a petición del titular de la acción respectiva, lo siguiente:

1. Decretar la separación de bienes de los cónyuges.

2. Autorizar a la mujer para actuar conforme a lo dispuesto en el inciso segundo del artículo 138 del Código Civil, sin que sea necesario acreditar el perjuicio a que se refiere dicho inciso.

3. Autorizar la salida del país de los hijos menores de edad sin necesidad del consentimiento del alimentante, en cuyo caso procederá en conformidad a lo dispuesto en el inciso sexto del artículo 49 de la ley No 16.618.

La circunstancia señalada en el inciso anterior será especialmente considerada para resolver sobre:

a) La falta de contribución a que hace referencia el artículo 225 del Código Civil.

b) La emancipación judicial por abandono del hijo a que se refiere el artículo 271, número 2, del Código Civil".

110 En este sentido, sentencia Corte de Apelaciones de Rancagua Martínez con Lobos (2007) y sentencia de la Corte de Apelaciones de Concepción Toro con Faúndez (2007).

111 En este sentido, sentencia de la Corte de Apelaciones de Rancagua González con Díaz (2010).

112 En este sentido, sentencia de la Corte de Apelaciones de Concepción Ibáñez con Miranda (2006).

113 En este sentido, sentencia de la Corte de Apelaciones de Concepción Ramírez con Godoy (2009). 
ves de salud o invalidez ${ }^{114}$, si la deuda es repactada ${ }^{115}$, si se deposita una cantidad inferior a la pactada ${ }^{116}$, o si solo existen diferencias en la reajustabilidad de la pensión ${ }^{117}$.

También, se ha discutido si el incumplimiento de los deberes alimenticios debe ser respecto de los hijos y el cónyuge ${ }^{118}$, o basta el incumplimiento respecto de uno de ellos, dada la conjunción copulativa " $y$ " que da a entender que debe haber incumplimiento respecto de ambos alimentarios. En este caso nuestra jurisprudencia ha señalado que "la finalidad de la disposición, cual es, sancionar la infracción a la obligación de socorro y el principio de protección al cónyuge más débil, que debe siempre ser respetado en estas materias, conducen necesariamente a concluir que corresponde igualmente desestimar la demanda sea que el incumplimiento haya sido con el cónyuge o con los hijos comunes"119.

Por último, se ha señalado que es una sanción civil carente de efecto retroactivo, por lo que no se aplicaría a los matrimonios celebrados antes de la entrada en vigencia de la ley, por aplicación de lo dispuesto en el artículo $9^{\circ}$ del Código Civil, de excepción y de interpretación restrictiva ${ }^{120}$, en contra, se ha sostenido que se aplica en forma retroactiva, es decir, a todos los matrimonios, incluidos aquellos que celebraron su matrimonio con anterioridad a la entrada en vigencia de la $\mathrm{NLMC}^{121}$, en virtud de lo dispuesto en el artículo $2^{\circ}$ transitorio NLMC ${ }^{122}$.

El peso de la prueba, según lo ha resuelto la Corte Suprema, corresponde al actor, por aplicación del artículo 1698 del Código Civil. Es decir, el alimentante y demandante de divorcio unilateral, deberá probar que ha cumplido su obligación alimentaria respecto a su cónyuge e hijos.

De esta forma la NLMC protege al cónyuge y a sus hijos ante los incumplimientos de los deberes alimenticios por parte del cónyuge que demanda en forma unilateral el divorcio por cese de convivencia ${ }^{123}$.

\footnotetext{
114 Así, sentencia de la Corte de Apelaciones de Concepción Muñoz con Orellana (2009). Situaciones que la propia Ley $\mathrm{N}^{\circ} 14.908$ reconoce para dejar sin efectos los apremios en casos de deudas de alimentos. Artículo 14 inciso final Ley $N^{\circ}$ 14.908: "Si el alimentante justificare ante el tribunal que carece de los medios necesarios para el pago de su obligación alimenticia, podrá suspenderse el apremio y el arraigo, y no tendrá aplicación lo dispuesto en el inciso cuarto. Igual decisión podrá adoptar el tribunal, de oficio, a petición de parte o de Gendarmería de Chile, en caso de enfermedad, invalidez, embarazo y puerperio que tengan lugar entre las seis semanas antes del parto y doce semanas después de él, o de circunstancias extraordinarias que impidieren el cumplimiento del apremio o lo transformaren en extremadamente grave".

115 En este sentido, Corte de Apelaciones de Santiago, sentencia Ribo con Pardo (2007).

116 Así, sentencia de la Corte de Apelaciones de Santiago Zenteno con Muñoz (2008).

117 En este sentido, sentencia de la Corte de Apelaciones de Valparaíso Olaechea con Vella (2010).

118 Barrientos y Novales (2004) p. 391.

119 Sentencia de la Corte de Apelaciones de Concepción Saravia con Guzmán (2007).

120 En este sentido, sentencia de la Corte Suprema Palavecino con Feres (2009); sentencia de la Corte de Apelaciones de Chillán Fuentes con Melo (2007); sentencia de la Corte de Antofagasta Campillay con Ferrada (2009) y, sentencia de la Corte de La Serena Contreras con Montecinos (2007).

121 Que fue publicada el 17 de mayo de 2004 y entró en vigencia seis meses después, es decir, el 18 de noviembre de 2004 (artículo final NLMC).

122 Sentencia de la Corte Suprema Fuentes con Melo (2007) y sentencia de la Corte de Apelaciones de Chillán Castro con García (2007).

123 Sentencia de la Corte de Apelaciones de Santiago Calderón con Araya (2007).
} 
Según el profesor René Ramos Pazos ${ }^{124}$, la sentencia que rechaza la demanda no produce cosa juzgada, de tal suerte que se puede volver a demandar, previo cumplimiento de los requisitos legales, es decir, nuevo cese de la convivencia, nuevo plazo de tres años y cumplir en forma regular durante este nuevo plazo los deberes alimenticios, con el cónyuge e hijos.

En cambio la Corte de Apelaciones de San Miguel, en sentencia 24 de diciembre de 2009, causa Rol 830-2009, que señala "resulta claro que en la sentencia aludida (de petición de divorcio por cese de la convivencia) no se resolvió el fondo del asunto, esto es, no existió un pronunciamiento sobre el fondo del derecho indubitado entre las partes, no se rindió prueba alguna a dicho respecto, en consecuencia produjo cosa juzgada formal, no pudo producir cosa juzgada material, en términos de impedir que sea renovada la acción en otro juicio y en cualquier tiempo".

\subsection{Las Facultades del JUEZ de aprobar un aCUERdo o CONVENio REgulador}

En el marco del denominado divorcio de mutuo acuerdo, los cónyuges deben presentar un acuerdo que regule de manera completa y suficiente sus relaciones mutuas y las materias relacionadas con los hijos comunes (artículo 55 NLMC).

En primer lugar, aunque la ley no lo señala, es necesario que el acuerdo conste por escrito, a lo menos por escritura privada (incluso no existe a nuestro juicio inconveniente en que se incorpore en un otrosí del escrito de la demanda o solicitud de divorcio), ya que el artículo 55 NLMC señala en forma imperativa que "debe acompañarse" (la única forma es que conste por escrito). En consecuencia, es un requisito de la acción de divorcio de común acuerdo. Visto de otra forma, es una carga para las partes, ya que en la práctica los cónyuges pueden estar de acuerdo en el divorcio, pero no necesariamente lo estarán en las otras materias de familia que deben regular en el convenio.

El acuerdo será completo si regula todas y cada una de las materias indicadas en el artículo 21 NLMC, es decir, las que dicen relación con las relaciones mutuas entre los cónyuges, a saber: a) los alimentos que se deban ${ }^{125}$; b) las materias vinculadas al régimen de bienes del matrimonio, es decir, la liquidación de la sociedad conyugal o la determinación del crédito de participación, esto último en el régimen de participación en los gananciales. El convenio debe regular, además, las materias respecto de los hijos comunes, que son: a) el cuidado personal; b) la pensión de alimentos; y, c) el régimen comunicacional o de relación directa y regular del padre que no tiene la custodia de los hijos.

\footnotetext{
124 Según Ramos: "Otra duda nos surge en relación con la situación que estamos tratando: ¿qué ocurre si se rechaza la demanda por no haber cumplido el demandante con esta obligación? ¿Quiere decir que nunca más podrá intentar la acción de divorcio? Pensamos que en este caso, este demandante, deberá expresar su voluntad de poner fin a la convivencia, en alguno de los instrumentos que indica el artículo 22 letras a) o b),o bien dejando constancia judicial en los términos señalados en el artículo 25 inciso $2^{\circ}$. Y a partir de ese momento cumplir con sus obligaciones alimenticias, esperando que transcurra un nuevo plazo de 3 años”. Ramos (2005b).

125 Debemos entender las deudas por pensiones alimentarias devengadas, ya que en virtud de lo dispuesto por el artículo 60 NLMC, "el divorcio pone fin a las obligaciones y derechos de carácter patrimonial cuya titularidad y ejercicio se fundan en la existencia del matrimonio, como los derechos sucesorios reciprocos y el derecho de alimentos", en consecuencia, no se puede regular una pensión de alimentos para el ex cónyuge.
} 
Todo lo anterior es lo que se denomina en el derecho español el contenido mínimo u obligatorio del convenio regulador, es decir, se trata de aquellas materias que se deben regular en forma obligatoria ${ }^{126}$.

Se trata de un acto complejo, en que se regulan una serie de materias de Derecho de Familia, y que cada una quedará sometida a las formalidades que para caso exige la ley. En el artículo 22 NLMC se consigna que la nulidad de una o más de las cláusulas de un acuerdo que conste por medio de alguno de los instrumentos señalados en el inciso primero, no afectará el mérito de aquel para otorgar una fecha cierta al cese de la convivencia.

Como se puede apreciar, el acuerdo no considera otras materias como por ejemplo la patria potestad que se rige, en subsidio, por el artículo 245 Código Civil, por lo que le corresponderá ejercerla al padre o madre que tiene el cuidado personal. Tampoco menciona el derecho a compensación económica, lo que se justifica porque el artículo 21 NLMC que regula el contenido mínimo, se encuentre ubicado en el párrafo de la separación de hecho, en que no procede compensación. Por otra parte, las partes pueden renunciar a ella, aceptándose la renuncia tácita si nada señalan.

Según lo prescrito en el artículo 55 inciso $2^{\circ}$ NLMC se entenderá que el acuerdo es suficiente si resguarda el interés superior de los hijos, procura aminorar el menoscabo económico que pudo causar la ruptura y establece relaciones equitativas, hacia el futuro, entre los cónyuges cuyo divorcio se solicita.

Respecto a lo anterior, cabe tener presente las siguientes consideraciones. En primer lugar, estos criterios deben aplicarse al contenido mínimo u obligatorio, es decir, el juez debe determinar si las materias reguladas cumplen convenientemente con el interés superior de los hijos y protege al cónyuge débil, pero no se trata de exigencias adicionales en cuanto a las materias que se deben regular. En segundo lugar, dicha norma es idéntica a la del artículo 27 NLMC, que señala cuándo un acuerdo es completo y suficiente en sede de separación judicial, por lo que, de aceptar la teoría que sostiene que es suficiente cuando regula la compensación económica, implicaría la obligación de regular una compensación en la separación judicial ${ }^{127}$, en circunstancias que la compensación no procede en estos casos.

Es fácil advertir que esta norma busca proteger al cónyuge desde el punto de vista económico, ya que por una parte para que sea completo se deben regular los alimentos que se deban (en este caso alimentos devengados) y lo concerniente al régimen patrimonial del matrimonio (disolución y liquidación de la sociedad conyugal o determinación del crédito de participación), y para que sea suficiente debe procurar aminorar el menoscabo económico que genera la ruptura y establezca relaciones equitativas para el futuro entre los cónyuges.

Por último, es necesario plantear cuál es el grado de intervención del juez en los acuerdos antes señalados, esto es, si se debe limitar a homologar la voluntad de las partes, o si, en cambio, puede modificar o completar el convenio regulador.

La interpretación de estos casos dependerá de la visión que cada uno tenga sobre la el margen de autonomía de la voluntad de los cónyuges versus la visión paternalista de la justicia de familia.

126 Cfr. VV. AA. (1989), y Cordero (2004).

127 Sobre el particular ver LePin (2010) pp. 104 y ss. 
En este sentido, si la visión es paternalista o asistencial, las facultades del juez no se limitan a la mera homologación, ya que por aplicación del principio de protección al cónyuge más débil el juez debe intervenir incluso modificando o complementando el acuerdo, aplicando por analogía el artículo 31 NLMC ${ }^{128}$.

Esta norma autoriza al juez en la sentencia a "subsanar sus deficiencias o modificarlo si fuere incompleto o insuficiente”; y, además, por aplicación del principio de actuación de oficio que inspira los procedimientos que se desarrollan ante los Tribunales de Familia ${ }^{129}$.

No compartimos dicho criterio, ya que resulta por lo menos dudosa la aplicación por analogía del citado artículo 31 NLMC, toda vez que esta norma solo puede aplicarse a la separación judicial. Además, existen razones que justifican la aplicación exclusiva de este precepto en esta materia, una de las cuales es la subsistencia del matrimonio ${ }^{130}$.

En este sentido se ha señalado que "lo que está claro es que el juez tiene facultades como para plantear una vía de solución, aplicando los artículos 3 y $852^{\circ}$ de la LMC, que admiten la intervención judicial, pero en casos calificados. De esta forma, nos parece que el juez podría solicitar la presentación de un nuevo convenio regulador a las partes"131.

Compartimos la opinión de Barcia, aunque no sus argumentos, en especial la referencia al artículo 85 inciso $2^{\circ}$ NLMC, que se refiere al deber del juez de oír al niño de acuerdo a su edad y madurez. Sin embargo, por aplicación de los principios consagrados en el artículo 3 NLMC, interés superior del hijo y la protección del cónyuge más débil, y entendiendo además que se trata de un requisito exigido por la ley para dar lugar al divorcio por cese de la convivencia de mutuo acuerdo, no basta la presentación formal del acuerdo, sino que será necesario que cumpla con los estándares de ser completo y suficiente, ponderación que corresponde exclusivamente al juez. En consecuencia, si las partes no presentan el acuerdo o es incompleto o insuficiente, el juez debe rechazar la acción. Aunque en la práctica el juez va a instar a las partes a modificar el acuerdo a efectos de proceder a su aprobación.

De esta forma, Barcia agrega "el juez no tiene facultades para imponer a las partes modificaciones al convenio regulador, dictando una sentencia que dé lugar al divorcio. Si ello fuera de este modo se daría lugar a una clase de divorcio que no está contemplada en la ley. Si el juez pudiere imponer un convenio regulador no se trataría de un divorcio de común acuerdo, por cuanto no habría consentimiento, ni tampoco se trataría de un divorcio unilateral por cese de convivencia. Y se daría lugar a un divorcio anómalo, que no está contemplado en nuestro derecho"132.

\footnotetext{
128 Artículo 31. Al declarar la separación, el juez deberá resolver todas y cada una de las materias que se señalan en el artículo 21, a menos que ya se encontraren reguladas o no procediere la regulación judicial de alguna de ellas, lo que indicará expresamente. Tendrá en especial consideración los criterios de suficiencia señalados en el artículo 27. El juez utilizará los mismos criterios al evaluar el acuerdo presentado o alcanzado por los cónyuges, procediendo en la sentencia a subsanar sus deficiencias o modificarlo si fuere incompleto o insuficiente.

En la sentencia el juez, además, liquidará el régimen matrimonial que hubiere existido entre los cónyuges, si así se le hubiere solicitado y se hubiere rendido la prueba necesaria para tal efecto.

129 Cfr. Vidal (2009) p. 71; Corral (2007a) p. 37; y Domínguez (2005c) p. 100.

130 Lepin (2012a) p. 16.

131 Barcia (2011) p. 311.

132 BARCIA (2011) p. 311.
} 
Por otro lado, la autorización para que intervenga el juez cobra importancia cuando no se ha regulado el denominado contenido mínimo, es decir, cuando el acuerdo es incompleto, o cuando, habiéndose regulado todas las materias del artículo 21 NLMC, no se compadecen con los criterios de suficiencia ya descritos ${ }^{133}$.

Finalmente, por una razón de orden práctico, si el juez no ha recibido prueba sobre las materias que se someten a su aprobación, por lo que si no dispone de ningún antecedente: ¿`cómo puede ponderar quién es el más débil?, ¿cómo puede analizar si el acuerdo protege suficientemente al más débil?, ¿¿dependerá de la intuición del juzgador? ${ }^{\text {134 }}$

\section{CONCLUSIONES}

El principio de protección del cónyuge más débil es uno de los principios rectores del moderno Derecho de Familia, su aplicación aparece como complementaria a otros principios como la protección de la familia, del matrimonio e incluso del principio de igualdad entre los cónyuges, operando al término del matrimonio para restablecer precisamente las relaciones equitativas entre ellos.

Desde este punto de vista, se observa cierta confusión en la doctrina en cuanto a la aplicación de dichos principios, pretendiendo aplicar el principio de protección del cónyuge más débil a instituciones como la sociedad conyugal, los bienes familiares o las pensiones de alimentos, que más bien son expresiones de la protección de la familia o la solidaridad familiar. La diferencia estriba en el objeto de protección, en el primero la protección al cónyuge débil se trata de proteger un interés individual, en cambio en el segundo, la protección de la familia se refiere a un interés colectivo.

Como se puede apreciar, la preocupación del legislador, expresada en el texto del artículo 3 NLMC y en las actas de la ley, e incluso en las indicaciones presentadas al proyecto de ley, está orientada a la protección de aquel cónyuge que queda en una situación de desmedro económico al término del matrimonio. Como consecuencia, la protección al cónyuge débil, está determinada por la situación económica, y por tanto, a pesar de que no se distingue expresamente, se refiere a la mujer, por la desigualdad económica, en cuanto a los ingresos que perciben, a las posibilidades de acceso al mercado laboral, como también por ser quienes se dedican en un gran porcentaje al cuidado de los hijos y a las labores domésticas.

La ley entiende que uno de los cónyuges (más débil) queda en una situación de desmedro económico frente al otro cónyuge (más fuerte) al momento al término del matrimonio, ya sea por divorcio o nulidad, que se traduce en sus escasas posibilidades de negociación. Lo que no es sinónimo de estado de necesidad, propio de las pensiones de alimentos, sino se trata más bien de evitar el menoscabo económico.

Este principio de protección al cónyuge débil, importa un mandato dirigido al juez llamado a resolver el conflicto en situaciones de quiebre matrimonial. En consecuencia, de

133 LePIN (2012a) p. 16.

134 Lepin (2012a) p. 16. 
acuerdo a lo dispuesto en el artículo 3 NLMC, su aplicación se restringiría a la ruptura, descartando su intervención durante la época que dure el matrimonio.

En concordancia con lo planteado, los mecanismos a través de las cuales se concreta este principio son: el derecho a compensación económica, la denominada cláusula de dureza y las facultades del juez para la aprobación del convenio regulador, en los casos de divorcio de común acuerdo.

\section{BIBLIOGRAFÍA CITADA}

Alcalde, Enrique (2003): Los principios generales del derecho (Santiago, Ediciones Universidad Católica de Chile) 278 pp.

Alexy, Robert (2008): Teoría de los derechos fundamentales, Centro de Estudios Políticos y Constitucionales (Madrid, segunda edición) $601 \mathrm{pp}$.

Barcia Lehmann, Rodrigo (2011): Fundamentos del Derecho de Familia (Santiago, Thompson Reuters) 572 pp.

Barcia Lehman, Rodrigo y Riveros Ferrada, Carolina (2011a): "El carácter extrapatrimonial de la compensación económica", Revista Chilena de Derecho, Vol. 38 N²: pp. 249-278.

Barcia Lehman, Rodrigo y Riveros Ferrada, Carolina (2011b): "El carácter extrapatrimonial de la compensación económica y su renuncia”, Revista de Derecho de la Pontifica Universidad Católica de Valparaíso, Valparaíso, 2º semestre, XXXVII: pp. 93-113.

Barrientos Grandón, Javier y Novales Alquézar, Aránzazu (2004): Nuevo Derecho Matrimonial Chileno (Santiago, Editorial LexisNexis, segunda edición) 472 pp.

Barrientos Grandón, Javier (2007): “La compensación económica como "Derecho” de uno de los cónyuges y "obligación” correlativa del otro. De sus caracteres", Revista Chilena de Derecho Privado, No 9: pp. 9-44.

Barros Bourie, Enrique (1991): "Proyecto para introducir en Chile la participación en los gananciales como régimen de bienes normal del matrimonio", en Familia y personas (Santiago, Editorial Jurídica de Chile) 203 pp.

Boletín del Senado 1759-18 de la Comisión de Constitución, Legislación, Justicia y Reglamento del Senado: "Aspectos económicos del divorcio", 170 pp.

Cespedes Muñoz, Carlos y Vargas Aravena, David (2008): "Acerca de la naturaleza jurídica de la compensación económica. La situación en Chile y en España”, Revista Chilena de Derecho, Vol. 35 No 3: pp. 439-462.

Cillero Bruñol, Miguel (1998): "El interés superior del niño en el marco de la Convención Internacional de los Derechos del Niño", Infancia, Ley y Democracia en América Latina (Santa Fe de Bogotá-Buenos Aires, Editorial Temis-Ediciones Depalma) 1.397 pp.

Cordero Cutillas, Iciar (2004): El convenio regulador en las crisis matrimoniales (Estudio Jurisprudencial) (Navarra, Editorial Aranzandi) 313 pp.

Corral Talciani, Hernán (2007a): "La compensación económica en el divorcio y la nulidad matrimonial”, Revista Chilena de Derecho, vol. $34 \mathrm{~N}^{\circ}$ 1: pp. 23-40.

Corral Talciani, Hernán (2007b): Bienes familiares y participación en los gananciales (Santiago, Editorial Jurídica de Chile, segunda edición) 207 pp. 
Corral Talciani, Hernán (2009): Derecho civil y persona humana. Cuestiones debatidas (Santiago, Editorial LegalPublishing) $254 \mathrm{pp}$.

Del Picó Rubio, Jorge (2010): Derecho Matrimonial Chileno (Santiago, AbeledoPerrot LegalPublishing) $484 \mathrm{pp}$.

Díez-Picazo, Luis y Gullón, Antonio (2006): Sistema de derecho civil, Volumen IV (Madrid, Editorial Tecnos) 560 pp.

Domínguez Hidalgo, Carmen (2005a): "Los principios que informan el Derecho de Familia chileno: su formulación clásica y su revisión moderna”, Revista Chilena de Derecho, vol. $32 \mathrm{~N}^{\circ}$ 2: pp. 205-218.

Domínguez Hidalgo, Carmen (2005b): "Compensación económica en la nueva ley de matrimonio civil”, Seminario del Colegio de Abogados, charla efectuada 13 de octubre, 28 pp.

Domínguez Hidalgo, Carmen (2005c): "El convenio regulador y la compensación económica: una visión de conjunto”, en: Assimakópulos Figueroa, Anastasia y Corral Talciani, Hernán (edits.), Matrimonio civil y divorcio, análisis crítico y criterios para la aplicación de la Ley $N^{\circ} 19.947$ (Santiago, Universidad de los Andes) pp. 91-122.

DorWkin, Ronald (1989): Los derechos en serio (Barcelona, Editorial Ariel Derecho) 508 pp.

Fanzolato, Eduardo (1993): Alimentos y reparaciones en la separación y en el divorcio (Buenos Aires, Depalma) $327 \mathrm{pp}$.

Fenouillet, Dominique (2008): Droit de la Famille (Paris, Dalloz, segunda edición), 517 pp. Fosar Benlloch, Enrique (1982): Estudio de Derecho de Familia (Madrid, Bosch, T. II, V. 1) pp.

Gómez de la Torre Vargas, Maricruz (2005): "Compensación económica en la nueva ley de matrimonio civil”, Seminario Colegio de Abogados, charla efectuada el 20 de octubre, $18 \mathrm{pp}$.

Gómez de la Torre Vargas, Maricruz (2007): El sistema filiativo chileno (Santiago, Editorial Jurídica de Chile) 379 pp.

González Castillo, Joel (2012): La compensación económica en el divorcio y la nulidad matrimonial (Santiago, Editorial Jurídica de Chile) $172 \mathrm{pp}$.

Guerrero Becar, José (2008): "Menoscabo y compensación económica. Justificación de una visión asistencial”, Revista Derecho, vol. 21 No 2: pp. 85-110.

HÜBner GuZMÁn, Ana (2005): "La nueva Ley de matrimonio civil: panorama y estructura general”, en: Assimakópulos Figueroa, Anastasia y Corral Talciani, Hernán (edits.), Matrimonio civil y divorcio, análisis crítico y criterios para la aplicación de la Ley $N^{\circ}$ 19.947 (Santiago, Universidad de los Andes) pp. 15-35.

Instituto Libertad y Desarrollo (2005): “Divorcio unilateral empeora la situación de la mujer”. Disponible en: <http://www.lyd.com/programas/legislativo/divorcio> [fecha de consulta: 10 de junio de 2005].

lalana del Castillo, Carlos (1993): La pensión por desequilibrio en caso de separación o divorcio (Barcelona, José María Bosch Editor S.A.) 302 pp.

Lepin Molina, Cristián (2008): "La pensión compensatoria en el derecho español", Revista del Magister y Doctorado en Derecho, Facultad de Derecho, Universidad de Chile, $\mathrm{N}^{\circ}$ 2: pp. 91-117. 
Lepin Molina, Cristián (2010): La compensación económica. Efecto patrimonial de la terminación del matrimonio (Santiago, Editorial Jurídica de Chile) 224 pp.

Lepin Molina, Cristián (2012a): "Autonomía de la voluntad y protección del cónyuge más débil en la determinación y formas de pago de la compensación económica”, Revista Ius et Praxis, año $18 \mathrm{~N}^{\circ}$ 1: pp. 3-35.

Lepin Molina, Cristián (2012b): "Formas de pago de la compensación económica. Autonomía de la voluntad y protección al más débil”, en: Elorriaga, Fabián (coord.), Estudios de Derecho Civil VII, Jornadas Nacionales de Derecho Civil (Santiago, Editorial AbeledoPerrot Thompson Reuters) pp. 87-103.

Lepin Molina, Cristián (2012c): "La compensación económica en la nueva ley de matrimonio civil chilena", Revista de Derecho de Familia y de las Personas (Buenos Aires, Editorial La Ley, año IV, Nº 7) pp. 81-96.

Malaurie, Philippe y Fulchiron, Hugues (2009): La Famille (Paris, Lextenso Éditions, tercera edición) $743 \mathrm{pp}$.

Méndez Costa, María Josefa (2006): Los principios Jurídicos en las Relaciones de Familia (Buenos Aires, Rubinzal-Culzoni Editores) 423 pp.

Novales Alquézar, Aránzazu (2010): "La compensación económica como derecho de familia matrimonial ¿Cuál es el objeto de la compensación?”, Revista Chilena de Derecho de Familia, $\mathrm{N}^{\circ}$ 1: pp. 35-72.

Orrego Acuña, Juan (2004): Análisis de la Nueva Ley de Matrimonio Civil (Santiago, Metropolitana) $195 \mathrm{pp}$.

Pizarro Wilson, Carlos y Vidal Olivares, Álvaro (2009): La compensación económica por divorcio o nulidad matrimonial (Santiago, LegalPublishing AbeledoPerrot) 157 pp.

Ramos Pazos, René (2005a): Derecho de Familia (Santiago, Editorial Jurídica de Chile, t. I, quinta edición actualizada febrero 2007) 370 pp.

Ramos Pazos, René (2005b): Aspectos destacados de la Ley 19.947, sobre matrimonio civil. Disponible en: <http://www.derecho.uct.cl/07publicaciones.htm> [fecha de consulta: 12 de julio de 2005].

Riveros Ferrada, Carolina (2012): "La relevancia del régimen patrimonial de los cónyuges para efectos de la determinación de la compensación económica”, Revista de Derecho, Universidad Católica del Norte, año $19 \mathrm{~N}^{\circ} 1$, pp. 417-430.

Roca Trías, Encarna (1999): Familia y cambio social (De la casa a la persona) (Madrid, Cuaderno Civitas) 277 pp.

Rodríguez Grez, Pablo (1996): Regímenes Patrimoniales (Santiago, Editorial Jurídica de Chile) $335 \mathrm{pp}$.

Rodríguez Grez, Pablo (2005): Ley de matrimonio civil. Disponible en: <www.abogados. cl> [fecha de consulta: 10 de junio de 2005].

Tapia Rodríguez, Mauricio (2005): Código Civil 1855-2055. Evolución y perspectiva (Santiago, Editorial Jurídica de Chile) 471 pp.

Tomasello Hart, Leslie (1994): El régimen de participación en los ganaciales (Santiago, Editorial Jurídica ConoSur Ltda.) 276 pp.

Veloso Valenzuela, Paulina (2007): "Algunas reflexiones sobre la compensación económica”, en: Grosman, Cecilia (dir.) y Herrera, Marisa (coord.), Hacia una armoni- 
zación del Derecho de Familia en el Mercosur y paises asociados (Buenos Aires, Editorial LexisNexis) pp. 167-184.

Vidal Olivares, Álvaro (2006): "La compensación por menoscabo económico en la ley de matrimonio civil”, en VIDAL, Álvaro (coord.) El nuevo derecho chileno del matrimonio (Santiago, Editorial Jurídica de Chile) pp. 217-287.

Vidal Olivares, Álvaro (2009) "Formas de pago y la protección del derecho a la compensación económica por divorcio o nulidad”, Revista Chilena de Derecho Privado, N 12: pp. 69-99.

Vodanovic Haklicka, Antonio (2004): Derecho de alimentos (Santiago, Editorial LexisNexis) 286 pp.,

VV. AA. (1989): Convenios reguladores de las relaciones paterno-filiales y patrimoniales en las crisis del matrimonio (Navarra, Ediciones Universidad de Navarra, segunda edición) 445 pp.

VV. AA. (2006): El contenido del convenio regulador. Sus diferentes aspectos, en: LLopis GINer, Juan Manuel (coord.) (Madrid, Colegio de Registradores de la Propiedad y Mercantiles de España) 501 pp.

ZARRALUQUi, Luis (2003): La pensión compensatoria de la separación conyugal y el divorcio (Valladolid, Editorial Lex Nova, segunda edición) 481 pp.

\section{JURISPRUDENCIA CITADA}

Ibánez con Miranda (2006): Corte de Apelaciones de Concepción, 3 de julio de 2006 (acción de divorcio), Rol 996-2006

Flores con Mora (2006): Corte de Apelaciones de Talca, 13 de septiembre de 2006 (acción de divorcio), Rol 720- 2006.

Cabezas con Silva (2007): Corte de Apelaciones de San Miguel, 6 de septiembre de 2007 (acción de divorcio), Rol 1286-2007.

Fuentes con Melo (2007): Corte de Apelaciones de Chillán, 30 de abril de 2007 (acción de divorcio), Rol 600-2006.

Martinez con Lobos (2007): Corte de Apelaciones de Rancagua, 30 de abril de 2007 (acción de divorcio), Rol 681-2006.

Toro con Faúndez (2007): Corte de Apelaciones de Concepción, 25 de mayo de 2007 (acción de divorcio), causa Rol 1314-2007.

Fuentes con Melo (2007): Corte Suprema, 30 de julio de 2007 (acción de divorcio), Rol 2718-2007.

Guzmán con Filippi (2007): Corte de Apelaciones de Santiago, 24 de octubre de 2007 (acción de divorcio), Rol 6710-2006.

Contreras con Montecinos (2007): Corte de Apelaciones de La Serena, 16 de noviembre de 2007 (acción de divorcio), Rol 386-2007.

Sasmay con Oliver (2007): Segundo Juzgado de Familia de Santiago, 21 de noviembre de 2007 (acción de divorcio), Rit 6930-2006.

Castro con García (2007): Corte de Apelaciones de Chillán, 7 de diciembre de 2007 (acción de divorcio), Rol 249-2007. 
Calderón con Araya (2007): Corte de Apelaciones de Santiago, 20 de diciembre de 2007 (acción de divorcio), Rol 1819-2007.

Saravia con Guzmán (2007): Corte de Apelaciones de Concepción, 21 de diciembre de 2007 (acción de divorcio), causa Rol 1549-2007.

Ribo con Pardo (2007): Corte de Apelaciones de Santiago, 24 de diciembre de 2007 (acción de divorcio), Rol 10411-2006.

Álvarez con Raimilla (2007): Corte de Apelaciones de Valdivia, 23 de julio de 2007 (acción de divorcio), Rol 530-2007.

Cabezas con Silva (2007): Corte de Apelaciones de San Miguel, 6 de septiembre de 2007 (acción de divorcio), Rol 1286-2007.

Bustos con Fernández (2007): Corte de Apelaciones de Santiago, 26 de enero de 2007 (acción de divorcio), Rol 676-2006.

Zenteno con Muñoz (2008): Corte de Apelaciones de Santiago, 25 de enero de 2008 (acción de divorcio), Rol 3049-2006.

Lagos con Monsalve (2008): Corte Suprema, 11 de diciembre de 2008 (acción de divorcio), Rol 6218-2008.

Campillay con Ferrada (2009): Corte de Antofagasta, 5 de febrero de 2009 (acción de divorcio), Rol 1303-2008.

Ramírez con Godoy (2009): Corte de Apelaciones de Concepción, 24 de febrero de 2009 (acción de divorcio), Rol 1707-2008.

López con Galdames (2009): Primer Juzgado de Familia de Santiago, 27 de mayo de 2009 (acción de divorcio), causa Rit 5980-2007.

Palavecino con Feres (2009): Corte Suprema, 15 de junio de 2009 (acción de divorcio), Rol 3175-2009.

Salgado con Bustos (2009): Corte Suprema, 29 de julio de 2009 (acción de divorcio), Rol 3911-2009.

Muñoz con Orellana (2009): Corte de Apelaciones de Concepción, 5 de noviembre de 2009 (acción de cese de alimentos), Rol 277-2009.

Aravena con Ramirez (2009): Corte de Apelaciones de Concepción, 11 de noviembre de 2009 (acción de divorcio), Rol 389-2009.

Elgueta con Piñeyro (2009), Corte Suprema, 29 de enero de 2009 (acción de divorcio), Rol 6744-2008. León con Valdivia (2010): Corte de Apelaciones de Copiapó, 18 de febrero de 2010 (acción de divorcio), Rol 118-2009.

Acuña con Orozco (2010): Corte Suprema, 7 de junio de 2010 (acción de divorcio), Rol 2857-2010.

Díaz con Fonsekas (2010): Corte Suprema, de 5 de julio de 2010 (acción de divorcio), causa Rol 2018-2010.

Olaechea con Vella (2010): Corte de Apelaciones de Valparaíso, 6 de julio de 2010 (acción de divorcio), Rol 166-2010.

González con Díaz (2010): Corte de Apelaciones de Rancagua, 4 de noviembre de 2010 (acción de divorcio), Rol 261-2010.

Gómez con Anabalón (2010): Corte Suprema, 13 de diciembre de 2010 (acción de divorcio), Rol 5765-2010. 
Lepin Molina, Cristián — "El principio de protección del cónyuge más débil en el moderno Derecho de Familia"

Barrientos con Barrrientos (2010): Corte Suprema, 28 de diciembre de 2010 (acción de cumplimiento de alimentos), Rol 6602-2010.

Malebrán con Corral (2011): Corte Suprema, 23 de mayo de 2011 (acción de divorcio), Rol 1126-2011.

Henzi con Plaza (2011): Corte de Apelaciones de Temuco, 19 de abril de 2011 (acción de divorcio), Rol 336-2010.

Ruiz con Vial (2011): Corte de Apelaciones de Santiago, 23 de agosto de 2011 (acción de divorcio), Rol 2564-2010.

Espinoza con Miranda (2012): Corte Suprema, 23 de mayo de 2011 (acción de divorcio), Rol 1413-2011.

González con Brito (2012): Corte Suprema, 23 de febrero de 2012 (acción de divorcio), Rol 10403-2011.

Zenteno con Zenteno (2012): Corte de Apelaciones de Concepción, 12 de noviembre de 2012 (acción de cumplimiento de alimentos), Rol 356-2012.

Beas con Campos (2012): Corte de Apelaciones de Talca, 9 de marzo de 2012 (acción de divorcio), Rol 2- 2012.

Baumgartner con Heinrich (2012): Corte de Apelaciones de Valdivia, 16 de febrero de 2012, (acción de divorcio), Rol 268-2011.

\section{NORMAS CITADAS}

Código Civil alemán.

Código Civil argentino.

Código Civil chileno.

Código Civil español.

Código Civil francés.

Ley 14.908, sobre Abandono de Familia y Pago de Pensiones Alimenticias. Diario Oficial, 5 de octubre 1962. Última modificación Ley 20.152. Diario Oficial, 9 de enero 2007.

Ley 19.947, que establece Nueva Ley de Matrimonio Civil. Diario Oficial, 17 de mayo de 2004.

Ley No 19.968, que crea los Tribunales de Familia. Diario Oficial, 15 de septiembre de 2008. 